Review

\title{
Enteroendocrine Hormone Secretion and Metabolic Control: Importance of the Region of the Gut Stimulation
}

\author{
Cong Xie ${ }^{1}\left(\mathbb{D}\right.$, Karen L. Jones ${ }^{1,2} \mathbb{C}$, Christopher K. Rayner ${ }^{1,3}$ and Tongzhi $\mathrm{Wu}^{1,2,4, *(\mathbb{C})}$ \\ 1 Adelaide Medical School and Centre of Research Excellence (CRE) in Translating Nutritional Science to \\ Good Health, The University of Adelaide, Adelaide 5005, Australia; c.xie@adelaide.edu.au (C.X.); \\ karen.jones@adelaide.edu.au (K.L.J.); chris.rayner@adelaide.edu.au (C.K.R.) \\ 2 Endocrine and Metabolic Unit, Royal Adelaide Hospital, Adelaide 5005, Australia \\ 3 Department of Gastroenterology and Hepatology, Royal Adelaide Hospital, Adelaide 5005, Australia \\ 4 Institute of Diabetes, School of Medicine, Southeast University, Nanjing 210009, China \\ * Correspondence: tongzhi.wu@adelaide.edu.au
}

Received: 31 July 2020; Accepted: 19 August 2020; Published: 21 August 2020

\begin{abstract}
It is now widely appreciated that gastrointestinal function is central to the regulation of metabolic homeostasis. Following meal ingestion, the delivery of nutrients from the stomach into the small intestine (i.e., gastric emptying) is tightly controlled to optimise their subsequent digestion and absorption. The complex interaction of intraluminal nutrients (and other bioactive compounds, such as bile acids) with the small and large intestine induces the release of an array of gastrointestinal hormones from specialised enteroendocrine cells (EECs) distributed in various regions of the gut, which in turn to regulate gastric emptying, appetite and postprandial glucose metabolism. Stimulation of gastrointestinal hormone secretion, therefore, represents a promising strategy for the management of metabolic disorders, particularly obesity and type 2 diabetes mellitus (T2DM). That EECs are distributed distinctively between the proximal and distal gut suggests that the region of the gut exposed to intraluminal stimuli is of major relevance to the secretion profile of gastrointestinal hormones and associated metabolic responses. This review discusses the process of intestinal digestion and absorption and their impacts on the release of gastrointestinal hormones and the regulation of postprandial metabolism, with an emphasis on the differences between the proximal and distal gut, and implications for the management of obesity and T2DM.
\end{abstract}

Keywords: nutrient digestion; nutrient absorption; gastrointestinal hormone; postprandial glycaemia; energy intake; region of the gut; obesity; type 2 diabetes

\section{Introduction}

As the key interface between ingested nutrients and the body, the gastrointestinal tract is now recognised to play a central role in regulating postprandial metabolism. During the fasting state, ghrelin is released from the gastric Gr-cells to drive food intake [1]. After meal ingestion, the stomach accommodates the nutrients, grinds digestible solids into small particles, and releases the resultant chyme into the small intestine in a regulated fashion to optimise intestinal digestion and absorption. It is now widely appreciated that distinctive enteroendocrine cells (EECs) scattered along the gastrointestinal tract, comprising up to $1 \%$ of the gut epithelium, constitute the largest endocrine organ in the body, accounting for the release of an array of peptides that orchestrate appetite, energy intake and the blood glucose responses to meals [2]. Of particular importance are cholecystokinin (CCK) and glucose-dependent insulinotropic polypeptide (GIP) released from the upper small intestine, and glucagon-like peptide-1 (GLP-1) and peptide YY (PYY) secreted mainly from the distal gut. These integrated hormonal responses convey 
important regulatory signals governing subsequent gastric emptying, insulin and glucagon secretion from the pancreas, energy intake, and postprandial glycaemic control. Stimulation of gastrointestinal postprandial hormone secretion, therefore, represents an attractive strategy for the management of metabolic disorders, such as obesity and type 2 diabetes mellitus (T2DM) [2]. Given that the distribution of the respective types of EECs varies substantially along the gastrointestinal tract, the region of the gut exposed to intraluminal stimuli is likely to be of major relevance to the secretion profile of gastrointestinal hormones and associated metabolic responses. This review discusses nutrient digestion and absorption along the gastrointestinal tract and how these processes influence the secretion of GIP, CCK, GLP-1 and PYY, and highlights the importance of which region of the gut is stimulated to the secretory profiles of these gastrointestinal hormones, the regulation of postprandial metabolism, and the implications for the management of obesity and T2DM. Other hormones, such as ghrelin and leptin, are also important metabolic regulators, but are not specifically discussed as they are outside the scope of this review.

\section{Nutrient Transport, Digestion, and Absorption}

Following meal ingestion, the stomach stores the ingested content and grinds digestible solids into small particles prior to delivering them into the small intestine. The latter occurs at a relatively constant caloric rate (in the range of $1-4 \mathrm{kcal} / \mathrm{min}$ in healthy individuals), driven by antral and duodenal contractions against tonic and phasic pyloric pressures [3], to optimise the subsequent digestion and absorption of nutrients in the small intestine. Due to the inactivation of salivary amylase in the gastric environment, there is limited digestion of carbohydrate in the stomach, whereas fat and protein are digested into lipid emulsions [4] and oligopeptides [5], respectively. Upon entering the duodenum, nutrients stimulate the release of a range of digestive enzymes from the exocrine pancreas and bile acids from the gallbladder, influenced by both the load and composition of the meal. Starch is broken down by pancreatic $\alpha$-amylase and disaccharidases into glucose and other monosaccharides (e.g., fructose and galactose) [6]. Dietary fat (90-95\% in the form of triglycerides) is digested by pancreatic lipase, a process relying largely on emulsification by bile acids, to form monoacylglycerol, glycerol and free fatty acids [4]. Digestion of protein involves both pancreatic enzymes, including chymotrypsin and trypsin, and aminopeptidases secreted by the small intestine mucosa, and yields individual amino acids, dipeptides and tripeptides [5].

The digestive products are transported by peristalsis and absorbed by passive diffusion and/or active transport via distinctive transporters at specific regions of the gut. For example, absorption of glucose involves both active transport from the lumen into the enterocytes via sodium-glucose cotransporter 1 (SGLT-1) and facilitated diffusion across the basolateral side of enterocytes through the glucose transporter 2 (GLUT2), taking place predominantly in the upper small intestine [7-10]. Unlike glucose, fructose is absorbed mainly through GLUT5 [11], which is well expressed in both the human jejunum and ileum [12]. Dietary fat typically binds to bile acids to form mixed micelles, which are absorbed by fatty acid transport proteins (FATPs) (e.g., FATP4 and FAT/CD36) and Niemann-Pick C1 like-1 (NPC1L1) [13,14]. Although a small fraction of bile acids are absorbed passively in the jejunum, the majority of them ( $90 \%)$ are actively absorbed in the ileum through the apical sodium-dependent bile acid transporter (ASBT) [15]. The uptake of amino acids depends on a variety of "amino acid transport systems" that preferentially transport amino acids of similar biophysical properties [16,17], whereas dipeptides and tripeptides are absorbed via the proton-dependent intestinal peptide transporter 1 (PEPT1) [18]. The large intestine hosts a diversity of gut bacteria, which are involved in the fermentation of products that escape digestion/absorption in the small intestine, such as dietary fibre, resistant starches and proteins, leading to the production of short-chain fatty acids (SCFAs) which can be absorbed through facilitated diffusion [19-21]. 


\section{Secretion and Actions of Gastrointestinal Hormones}

While intestinal EECs maintain a low secretory profile during fasting, the interaction between intraluminal contents and EECs during the digestive process represents the main driver of the secretion of gastrointestinal hormones. The latter, including GLP-1, GIP, CCK and PYY released from distinctive EECs in various regions of the gastrointestinal tract (Figure 1), are now recognised as key regulators of energy intake and postprandial glucose metabolism (Figure 2).

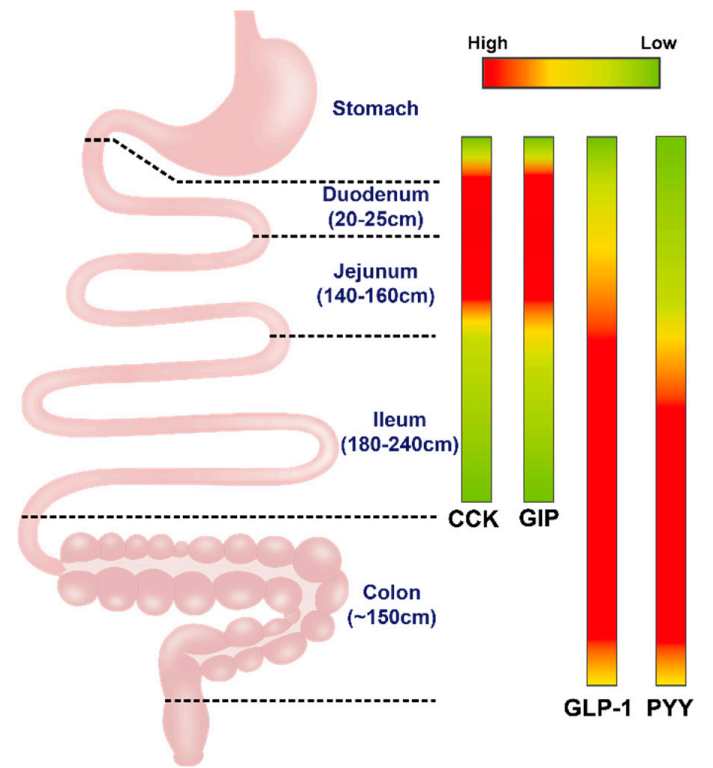

Figure 1. The density of enteroendocrine cells (EECs) secreting cholecystokinin (CCK), glucose-dependent insulinotropic polypeptide (GIP), glucagon-like peptide 1 (GLP-1) and peptide YY (PYY) in the duodenum, jejunum, ileum and colon.

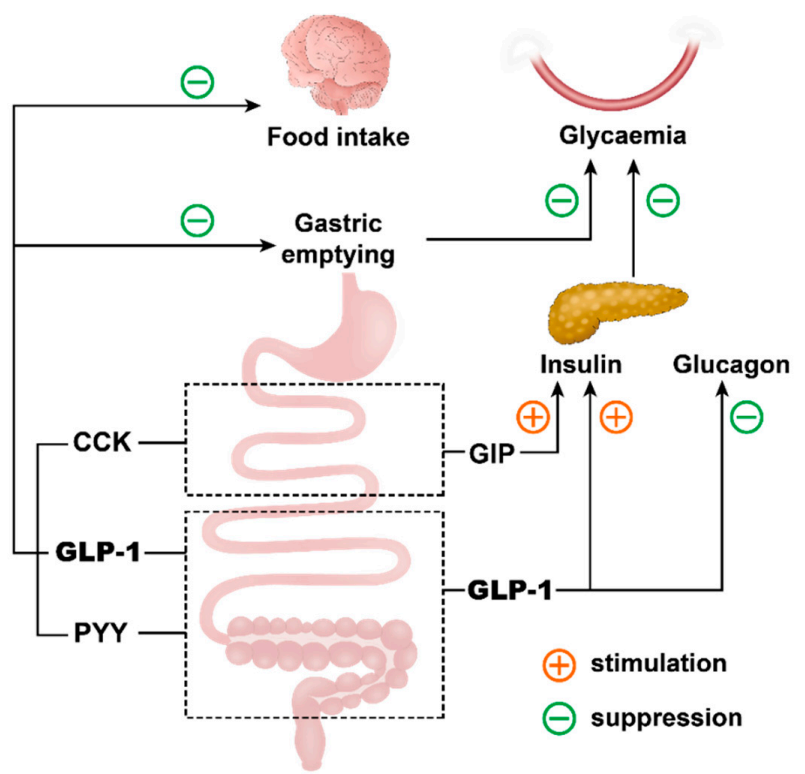

Figure 2. The roles of gastrointestinal hormones, including cholecystokinin (CCK), glucose-dependent insulinotropic polypeptide (GIP), glucagon-like peptide 1 (GLP-1) and peptide YY (PYY), released in response to meal ingestion, in the regulation of gastric emptying, postprandial glycemia and energy intake.

EECs are equipped with a variety of chemo-sensors linking the sensing of intraluminal stimuli to the secretion of gastrointestinal hormones. For example, carbohydrates can be detected by both 
their sweet taste through sweet taste receptors (STRs) [22-24], and via the glucose transporters, SGLT-1 and GLUT2 $[25,26]$, although stimulation of STRs by artificial sweeteners alone does not seem to be sufficient to induce GLP-1 or GIP secretion in humans [23,27]. EEC sensing of intraluminal fat is dependent on the degree of its digestion [28-30] and involves a number of $G$ protein-coupled receptors (GPRs), such as GPR40, GPR119 and GPR120 [31-33], and intestinal fat transporters FATP4 and FAT/CD36 [34,35]. Amino acids are detected by the calcium-sensing receptors (CasR) $[25,36]$ and amino acid transporters $[37,38]$. Non-nutritive compounds are also effectively sensed by EECs. In particular, bile acids are known to induce GLP-1 and PYY secretion via inhibition of nuclear farnesoid X receptor (FXR) [39] and/or stimulation of Takeda G-protein coupled receptor 5 (TGR-5) [40,41]. Of note, TGR5 is expressed on the basolateral membrane of EECs [42], such that intestinal bile acid absorption is necessary to achieve TGR5 activation [41,42]. There is recent evidence that a group of specialized GPRs responsible for the sensing of bitter taste (i.e., bitter taste receptors; BTRs) are also abundantly expressed on EECs. Activation of BTRs on EECs by a variety of natural or chemosynthetic bitter taste compounds, therefore, has the potential to trigger the secretion of gastrointestinal hormones [43].

\subsection{Glucagon-Like Peptide-1 (GLP-1)}

GLP-1 is secreted from the enteroendocrine L-cells located mainly in the ileum and colon in response to each of the macronutrients, although fat, relative to glucose and protein, is generally more potent at stimulating GLP-1 secretion when administered into the duodenum in humans [44,45]. However, in patients who have undergone Roux-en-Y gastric bypass, oral ingestion of glucose was shown to be more effective than fat or protein to stimulate GLP-1 secretion [46]. The discrepancy observed in the latter is likely to be attributable to the influence of gastric emptying and digestion of fat or protein. Other bioactive compounds released into the lumen following meal ingestion, such as bile acids, are also responsible for postprandial GLP-1 secretion [41,47]. After its secretion, GLP-1 is rapidly inactivated by the enzyme dipeptidyl peptidase IV (DPP-4) with a half-life of 1-2 min, such that only $10-15 \%$ intact GLP-1 reaches the peripheral circulation [48,49]. While obesity is associated with attenuated GLP-1 secretion, accumulating evidence suggests that the latter is otherwise unaltered in patients with T2DM [50,51]. Importantly, the action of GLP-1 is also relatively well preserved in T2DM [51].

GLP-1 binds to its receptor, expressed in a variety of metabolic tissues, to regulate glucose, lipid and energy metabolism. Within the pancreas, GLP-1 stimulates insulin secretion from the pancreatic $\beta$-cells and suppresses glucagon secretion from the $\alpha$-cells in a glucose-dependent manner [52]. For this reason, GLP-1-based glucose-lowering therapies, in general, entail a low risk of hypoglycaemia. Although there is preclinical evidence that GLP-1 receptor signalling is involved in $\beta$-cell survival and regeneration [53], such effects have not been established in humans. Within the liver, GLP-1-signalling is linked to the control of endogenous glucose production, an effect that can be independent of changes in insulin or glucagon [54]. Moreover, GLP-1 slows gastric emptying in both healthy individuals and those with T2DM [55-58]. That the reduction in postprandial glycaemia induced by exogenous GLP-1 is associated with less, rather than more, postprandial insulin secretion suggests that the slowing of gastric emptying outweighs its insulinotropic effect in controlling postprandial glycaemia [59]. In contrast to the GLP-1 receptor agonists, the DPP-4 inhibitors-which prolong the half-life of endogenous GLP-1-have little, if any, effect on gastric emptying [60,61].

Effects of GLP-1 signalling on lipid metabolism have been noted in both preclinical and clinical studies. GLP-1 has been shown to inhibit the production of lipid proteins (e.g., apolipoprotein B-48 (apob-48)) that are involved in the synthesis and transport of chylomicrons in the enterocytes, thereby improving lipid metabolism in rodents [62,63]. Similarly, the GLP-1 receptor agonist, exenatide, and the DPP-4 inhibitor, sitagliptin, have been shown to reduce plasma apob-48 concentrations in humans [64,65], while in obesity, treatment with GLP-1 receptor agonists improves dyslipidaemia [66].

GLP-1 also has the capacity to regulate energy intake and expenditure. Both exogenous GLP-1 and the GLP-1 receptor agonists suppress energy intake [50,67], and this effect has been shown to 
be mediated primarily via vagal afferents $[68,69]$ and the activation of GLP-1 receptors in the central nervous system [70,71]. GLP-1 receptor agonists are therefore often associated with weight loss in both obesity and T2DM [48,72]. The role of GLP-1 in the regulation of energy expenditure is controversial. In mice, GLP-1 receptor agonists have been reported to induce browning of white adipose tissue and increase $\beta$-oxidation of fatty acids [73-75], and administration of both GLP-1 receptor agonists and DPP-4 inhibitors increases energy expenditure and reduces body weight [75-78]. However, a recent meta-analysis suggests that GLP-1 receptor agonists have little, if any, effect on energy expenditure in humans [79]. Although inhibition of DPP-4 by vildagliptin was found to augment the energy expenditure response to an intraduodenal fat infusion in healthy humans [80], this effect was not evident in patients with T2DM [81]. That antagonism of GLP-1 signalling by exendin (9-39) increased energy expenditure in the latter group during treatment with vildagliptin suggests that endogenous GLP-1 signalling may rather be associated with suppression of energy expenditure [81].

\subsection{Glucose-Dependent Insulinotropic Polypeptide (GIP)}

GIP is released from the enteroendocrine K-cells, distributed predominantly in the upper small intestine [51]. GIP is also co-expressed with GLP-1 in a subset of "K/L-cells" in the duodenum and proximal jejunum [82,83]. Similar to GLP-1, GIP is released in response to macronutrients-with fat being a more potent stimulus than glucose or protein [44] - and rapidly inactivated by DPP-4 after secretion [51,84]. However, the secretion of GIP does not seem to be affected by T2DM or obesity [50].

In health, GIP stimulates insulin secretion in a glucose-dependent manner by binding to the GIP receptor expressed on the pancreatic $\beta$-cells [85], which contributes equally with GLP-1 to the augmented insulin response that is observed during enteral glucose administration when compared to an "isoglycaemic" intravenous glucose infusion, i.e., the so-called the "incretin effect". However, the insulinotropic effect of GIP is markedly diminished in patients with T2DM $[49,86]$. Unlike GLP-1, GIP stimulates glucagon secretion from the pancreatic $\alpha$-cells, particularly in the face of hypoglycaemia [87], and has little effect on appetite [88] or gastrointestinal motility [89]. Moreover, GIP exhibits numerous extra-glycaemic actions; blockade of GIP signalling in mice preferentially increases fat oxidation [90-92], reduces fat accumulation in adipocytes [90,92,93] and skeletal muscle [91,92], decreases triglyceride deposition in the liver $[90,93]$, and prevents the development of obesity $[90,91,94]$ in the context of overfeeding. In line with these findings, the antagonism of the GIP receptor is associated with reduced blood flow and triglyceride deposition in adipose tissue in healthy subjects [95]. Although compounds that display dual GIP and GLP-1 receptor agonism appear to be more effective for weight loss and glycaemic control than the GLP-1 receptor agonists, liraglutide and dulaglutide, in patients with T2DM [96,97], the relative contribution of GIP signalling to this superiority remains to be characterized in humans. Counterintuitively, acute administration of exogenous GIP failed to show any effect on energy intake or expenditure, but rather, augmented postprandial glycaemia in patients with T2DM receiving long-acting GLP-1 receptor agonists [98]. The mechanism underlying this phenomenon is unclear, but may be related to the stimulation of glucagon by intravenous GIP administration [86,98].

\subsection{Cholecystokinin (CCK)}

CCK is secreted from the enteroendocrine I-cells located in the duodenum and upper jejunum [1]. In mice, there is also evidence that a subset of EECs co-express CCK, GIP, GLP-1 and PYY in the proximal small intestine $[83,99]$. However, this is unlikely to be the case in humans, since exposure to glucose in the proximal $60 \mathrm{~cm}$ segment of the small intestine, while inducing substantial GIP and CCK secretion, does not affect GLP-1 secretion [100]. CCK is secreted within 10-15 min in response to oral ingestion of macronutrients (fat $>$ protein $>$ carbohydrate) [1]. This is critical for subsequent digestion since CCK stimulates the release of digestive enzymes and bile from the pancreas and the gallbladder, respectively.

Exogenous CCK is reported to attenuate the postprandial glycaemic excursion in humans. This effect is secondary to the slowing of gastric emptying, rather than a direct effect on glucose 
metabolism; intravenous administration of CCK at physiological doses diminishes the glycaemic response to an oral, but not an intraduodenal, glucose load in healthy males [101]. Similarly, in patients with well-controlled T2DM, the administration of CCK at a physiological dose $(0.4 \mathrm{pmol} / \mathrm{kg} / \mathrm{min})$ was shown to slow gastric emptying and reduce postprandial blood glucose excursions [102]. However, for those with longstanding T2DM, both the secretion and action of CCK appear to be impaired, due probably to the development of autonomic neuropathy $[3,103]$. In addition to its effects on upper gastrointestinal motor function, CCK has an established role in the regulation of appetite through both vagal and endocrine pathways. In rats, the effect of exogenous CCK to suppress food intake was abolished by small-molecule CCK antagonists or after vagotomy [104]. Similarly, intravenous infusion of CCK at both physiological (0.6-0.8 pmol $/ \mathrm{kg} / \mathrm{min})$ and supraphysiological doses (1.8 and $2.6 \mathrm{pmol} / \mathrm{kg} / \mathrm{min}$ ) suppresses hunger and energy intake in healthy subjects [105-107], effects abolished in the presence of a CCK antagonist [108]. In a population-based study, genetic polymorphisms of the CCK receptor, e.g., increased CCK_H3 haplotype frequency, may be responsible for over-eating in obesity [109]. However, acute administration of exogenous CCK showed a comparable effect on suppressing appetite in non-diabetic obese and lean subjects [110].

\subsection{Peptide $Y Y(P Y Y)$}

PYY is a 36-amino-acid peptide co-released with GLP-1 from L-cells [111]. Like other gastrointestinal hormones, postprandial secretion of PYY is dependent on the composition and load of macronutrients [112-115]. In contrast to GLP-1 and GIP, enzymatic conversion of PYY1-36 to PYY3-36 by DPP-4 is necessary for the systemic effects of PYY, namely suppression of appetite and slowing of gastric emptying [1].

PYY participates in the regulation of appetite and energy intake. PYY-null mice exhibit increased daily food intake and weight gain when compared with wild type mice, and this phenotype is reversed with PYY3-36 administration [115]. PYY binds to Neuropeptide Y receptor Y2 (NPY2R), which is highly expressed in the hypothalamic arcuate nucleus [116]. That the effect of PYY on energy intake is abolished in NPY2R knockout mice and by the selective NPY2R antagonist BIIE0246, suggests a key role of NPY2R signalling in mediating the effect of PYY to suppress energy intake $[117,118]$. In healthy humans, postprandial PYY levels are positively correlated with changes in satiety scores $[119,120]$, and intravenous PYY(3-36) infusion (up to $0.8 \mathrm{pmol} / \mathrm{kg} / \mathrm{min}$ ) reduces food intake in a dose-dependent manner [121,122]. Recently, the long-acting PYY3-36 analogue, mAb-cycPYY, was shown to reduce food intake and body weight over 7 days in rhesus macaques, effects further augmented when combined with the GLP-1 receptor agonist, liraglutide [123].

PYY may be also involved in the regulation of postprandial glycaemia, given its effect to slow gastric emptying in both rodents and humans [124-127]. Furthermore, PYY may influence insulin secretin; PYY1-36, but not PYY3-36, was found to inhibit insulin secretion from the pancreatic $\beta$-cells ex vivo [128-130], and isolated islets from PYY-knockout mice showed higher glucose-induced insulin levels [131]. PYY-knockout mice exhibit relative hyperinsulinaemia during fasting and postprandially [132]. However, exogenous PYY infusion had little effect on glucose-stimulated insulin in healthy humans [133].

\section{Regional Differences in Nutrient Absorption and Gastrointestinal Hormone Secretion, and Associated Impact on Postprandial Glycemia and Appetite}

\subsection{Nutrient Absorption}

The upper small intestine (duodenum and proximal jejunum) represents a major site of nutrient absorption. Given that the delivery of nutrients into the small intestine is controlled by gastric emptying, it is not surprising that the rate of nutrient absorption (such as glucose) is related directly to the rate of gastric emptying [134]. In the case of glucose, the maximum capacity of absorption of the upper small intestine approximates $\sim 0.5 \mathrm{~g} / \mathrm{min}$ per $30 \mathrm{~cm}$ [135]. Of note, glucose transporters (SGLT-1, 
GLUT2 and GLUT5) are less abundant in the distal than proximal small intestine [9,136]. Accordingly, intra-ileal administration of glucose is associated with slower absorption than intraduodenal, in both healthy individuals and patients with T2DM [137]. Moreover, duodenal-jejunal bypass improves glucose tolerance, associated with a reduction in SGLT-1-mediated glucose absorption in both obese rats and T2DM patients [138-141]. Similarly, the expression of the majority of lipid transporters (e.g., FAT/CD36, FATP4 and NPC1L1) decreases from the duodenum and jejunum to the ileum in rodents [142-146], and fatty acid and cholesterol uptake is slower in the distal than proximal small intestine $[146,147]$. In mice, the ablation of FAT/CD36 and FATP4 is associated with impaired lipid absorption in the proximal $[145,148]$, but not in the distal $[145,149]$ small intestine. However, fatty acid transporters have been shown to be abundantly expressed in both proximal and distal small intestine in humans [150]. The expression of transporters of amino acids and peptides varies substantially along the gastrointestinal tract [16]. While the majority of digestive products of protein are absorbed in the proximal jejunum, a considerable proportion is also absorbed in other small intestinal segments [17]. Amino acid transporters are abundant in the distal jejunum and ileum [151], such that obese patients who have undergone Roux-en-Y gastric bypass (RYGB) exhibit accelerated uptake of amino acids [152]. The absorption of nutrients in the large intestine is minimal. Undigested nutrients are fermented by microbiota localised in the large intestine to produce SCFAs which can be absorbed passively across colonic mucosa.

\subsection{Gastrointestinal Hormone Secretion}

EECs secreting GIP, CCK, GLP-1 and PYY exhibit high regional specificity of distribution along the gastrointestinal tract. Their secretory profiles are, therefore, largely dependent on the region of the gut exposed to intraluminal stimuli. In response to meal ingestion, increments in plasma GIP and CCK usually occur earlier than those of GLP-1 and PYY [153], consistent with the proximal distribution of Kand I-cells, and distal predominance of L-cells. Studies employing intraduodenal infusion of nutrients at different rates that mimic the physiological range of gastric emptying have shown that the secretion of GIP and CCK increases in an approximately linear pattern with increasing rates of infusion in health, obesity and T2DM [154-161]. In obese and T2DM patients, both the GIP and CCK responses to oral meals are increased after Roux-en- $Y$ gastric bypass [162,163], due probably to rapid gastric pouch emptying [164]. However, postprandial GIP secretion is decreased after biliopancreatic diversion, since this procedure bypasses the majority of K-cell rich regions of the small intestine $[165,166]$. By contrast, intraduodenal infusion of nutrients needs to exceed a threshold (e.g., $\sim 2 \mathrm{kcal} / \mathrm{min}$ for glucose) for sufficient nutrient to escape proximal small intestinal absorption and stimulate more distal L-cells; accordingly, the GLP-1 response is minimal to intraduodenal glucose infusion at rates between $1-2 \mathrm{kcal} / \mathrm{min}$ but increases substantially in response to infusions of $3-4 \mathrm{kcal} / \mathrm{min}[155,158,159]$.

The extent to which nutrients are delivered to the more distal regions of the gut is dependent not only on their rate of entry to the small intestine but also on their digestion and absorption in the upper gut. For example, ablation or inhibition of SGLT-1 that reduces proximal intestinal glucose absorption augments the GLP-1 and PYY responses to oral glucose in rodents [167,168]. In humans, intestinal SGLT-1 inhibition (e.g., by GSK-1614235 [169] or licogliflozin [170]), while reducing GIP secretion, is associated with overall increased, albeit relatively delayed, responses of GLP-1 and PYY to carbohydrate meals. Similarly, malabsorption of carbohydrate induced by an $\alpha$-glucosidase inhibitor (e.g., acarbose) was shown to increase GLP-1 and PYY secretion in both health and T2DM [171,172]. Alternatively, poorly absorbed carbohydrates, such as tagatose [27], xylose [173] and resistant starch [174], also can induce sustained secretion of GLP-1. Consistent with this principle, consumption of a small amount of tagatose or xylose as a "preload" has been shown to slow gastric emptying and improve the glycaemic response to the subsequent main meal by stimulating GLP-1 secretion in both health and T2DM $[27,175]$. Treatment with the lipase inhibitor, orlistat, however, has been reported to either increase [176] or decrease [177-179] postprandial GLP-1 secretion. These discrepancies may have reflected differences 
in the test meals (including the forms of dietary fat) and the associated impact of orlistat on their digestion between studies.

Compared with intraduodenal infusion, administration of nutrients directly into the jejunum or ileum is more effective at stimulating GLP-1 and PYY secretion [137,180-186]. Interestingly, intra-ileal infusion of glucose is also associated with a considerable, albeit relatively lower, GIP response than intraduodenal infusion in both healthy subjects and patients with T2DM $[137,183]$, suggesting that a considerable number of EEC cells capable of secreting GIP are found even in the distal small intestine. The large intestine represents another major source of GLP-1 and PYY production. Microbial metabolites, including SCFAs and secondary bile acids, are known to stimulate GLP-1 and PYY secretion [47,187-193] and may also induce differentiation of stem cells towards L-cells [194]. Inhibition of ileal ASBT (by elobixibat), increasing the exposure of the large intestine to bile acids, is therefore associated with an increase in GLP-1 and PYY secretion in humans [195]. In both healthy individuals and patients with T2DM [196,197], rectal administration of primary bile acid, taurocholic acid (TCA), has also been shown to stimulate GLP-1 and PYY secretion in a dose-dependent manner, although the PYY response seems to be more robust than that of GLP-1.

\subsection{Regulation of Postprandial Glycaemia and Appetite}

As discussed, the upper gut coordinates the delivery of nutrients for intestinal digestion and absorption, and is primarily responsible for the release of GIP and CCK after meals, whereas the interaction of intraluminal nutrients and bioactive compounds with the distal gut gives rise to the secretion of both GLP-1 and PYY. These variations in nutrient absorption and gastrointestinal hormone secretion along the gastrointestinal tract are of major relevance to the regulation of postprandial glycaemia and appetite.

It is now widely recognised that the rate of gastric emptying represents a major determinant of the glycaemic profile in response to carbohydrates in both health and diabetes $[198,199]$. While obesity per se does not seem to have a major impact on gastric emptying [200], recent evidence suggests that gastric emptying in patients with "early-stage" uncomplicated type 1 and 2 diabetes is more rapid than in non-diabetic controls $[199,201]$, which may predispose them to glucose intolerance. By contrast, in patients with longstanding diabetes who have poor glycaemic control and autonomic dysfunction, gastric emptying is often abnormally delayed [202]. Nevertheless, nutritional and/or pharmacological strategies that slow gastric emptying have been shown to attenuate postprandial glycaemic excursions in both type 1 and 2 diabetes [57,203-205]. However, it should be noted that the relationship between the rise in postprandial blood glucose and the gastric emptying rate is not necessarily linear. Intraduodenal glucose infusion at $2 \mathrm{kcal} / \mathrm{min}$ results in a much greater increase in blood glucose levels than $1 \mathrm{kcal} / \mathrm{min}$ in healthy humans, while minimal additional increase occurs in glycaemia at rates of 3 or $4 \mathrm{kcal} / \mathrm{min}[155,158,159]$, due probably to the increasing contribution of the distal gut to provide counter-regulation to glycaemic excursions.

In health, GIP contributes to approximately $50 \%$ of the incretin effect [206] and may serve to stabilise blood glucose by stimulating glucagon secretion during hypoglycaemia [87]. However, the loss of the insulinotropic effect of GIP in T2DM, and the potential for GIP to increase fat deposition, have rendered it an unappealing target for the management of T2DM. Recently, novel compounds with dual GIP and GLP-1 receptor agonism have been developed to treat T2DM, with promising glucose-lowering efficacy [96]. However, as mentioned earlier, the relative contribution of GIP receptor agonism to the overall metabolic benefits of these compounds remains unclear. The rapid release of CCK in response to meal ingestion is necessary for the digestion of complex macronutrients, particularly fat, so it represents a determinant of subsequent gastric emptying and appetite responses.

However, when nutrients are administered intraduodenally, a threshold of the caloric load is required to achieve suppression of appetite [207], indicative of a greater relevance of stimulating the distal gut to the control of appetite. Indeed, relative to the upper gut, the lower gut appears to be more effective at mediating postprandial glucose metabolism and suppressing appetite due to substantially 
augmented GLP-1 and PYY secretion. Recently, the comparative effects of the proximal and distal small intestine on postprandial glucose metabolism were evaluated using targeted intraluminal glucose infusion in both healthy individuals and patients with T2DM [137]. In both groups, intra-ileal administration of glucose $(2 \mathrm{kcal} / \mathrm{min}$ over $60 \mathrm{~min}$ ) was associated with substantially greater GLP-1 secretion, incretin effect and gastrointestinal-mediated glucose disposal (GIGD), when compared with intraduodenal infusion (Figure 3). That the absorption of glucose occurs at a lower rate in the ileum, probably because of fewer glucose transporters in the distal gut, may not only attenuate the glycaemic response to glucose infusion but also allow EECs to be stimulated over a longer duration than those in the proximal gut [137]. In a similar study setting, Poppitt and colleagues compared the effects of a small load of glucose $(\sim 0.65 \mathrm{kcal} / \mathrm{min}$ over $90 \mathrm{~min})$, administered into either the ileum or the duodenum, on gastrointestinal hormone secretion, appetite and food intake in healthy subjects. In this study, ileal infusion of glucose-induced greater GLP-1 and PYY secretion and less food intake than did intraduodenal infusion [183]. Compared with oral ingestion or duodenal perfusion, delivering fat or protein into the ileum also induces a greater suppression of food intake in healthy humans $[185,186,208]$. Moreover, administration of a relatively small load of lauric acid (5 g; $20 \mathrm{kcal})$ in enterically coated pellets for release in the ileum and colon has been shown to stimulate sufficient GLP-1 secretion to improve the glycaemic response to a standardised breakfast and lunch in patients with T2DM [209]. Similarly, the ileocolonic delivery of mixed bile acids (1 g/day) increases GLP-1 secretion and reduces postprandial blood glucose levels in patients with obesity and T2DM during a 4-week treatment [210]. Alternatively, EEC stimuli can be delivered through rectal administration; rectal perfusion with TCA has been shown to stimulate GLP-1 and PYY secretion, and suppress appetite scores in health [196] and reduces energy intake and glycaemia in T2DM [197]. Accordingly, enhancing the exposure of the distal gut to nutrients, and associated bioactive compounds such as bile acids, either by pharmacological inhibition of nutrient digestion and absorption in the upper gut $[171,172]$, surgical reconstruction of the gastrointestinal tract (such as Roux-en-Y gastric bypass) [211,212], or endoscopic implantation of a duodenal-jejunal bypass sleeve device [140,141], has been shown to improve blood glucose control in T2DM and reduce body weight in obesity. The causal links of these metabolic outcomes to GLP-1 and PYY signalling have been further validated in T2DM patients undergoing Roux-en-Y gastric bypass, in whom glucose tolerance is attenuated by the GLP-1 receptor antagonist exendin9-39) [213,214], while energy intake is increased with either GLP-1 receptor antagonism, or inhibition of PYY activation using a DPP-4 inhibitor [215].

In recognition that the gut microbiota are an essential regulator of the host energy metabolism [216], and that insulin resistance, obesity and T2DM are linked to dysbiosis [217], the role of the large intestinal bacteria in the regulation of glycaemia and food intake is now receiving increasing attention. While the mechanisms by which the gut microflora participate in the regulation of metabolic homeostasis remain incompletely understood, many of their metabolites are linked to gastrointestinal hormone secretion [218,219]. For example, SCFAs, including acetate, butyrate and propionate, have been shown to stimulate GLP-1 and PYY from colonic L-cells in a dose-dependent manner [187,188,192] and to enhance insulin secretion either directly or indirectly in both rodents and humans [187-192]. Oral supplementation with propionate and butyrate improves blood glucose control and promotes weight loss in rats [220]. In obese individuals, acute administration of inulin-propionate ester (10 g), designed to be released in the colon, was shown to increase postprandial GLP-1 and PYY concentrations and decrease energy intake, without affecting gastric emptying [191]. Moreover, the administration of inulin-propionate ester ( $10 \mathrm{~g} /$ day) over 24 weeks showed a tendency to reduce body weight in obese subjects [191]. However, this phenomenon is complicated by evidence of a central effect contributing to the suppression of energy intake after a single dose of colonic inulin-propionate ester, independent of changes in peripheral GLP-1 or PYY concentrations [221]. 


\section{Healthy subjects}
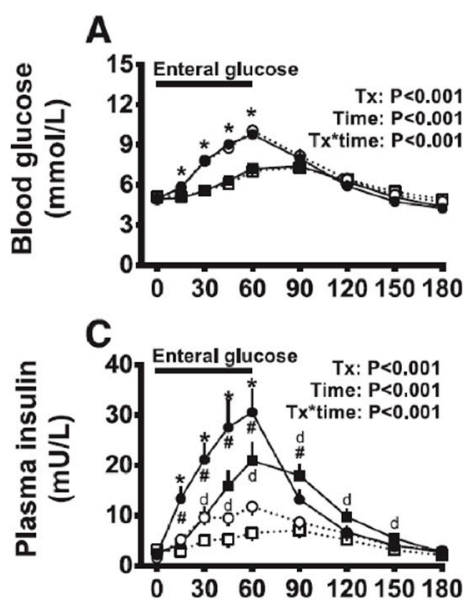

$E$
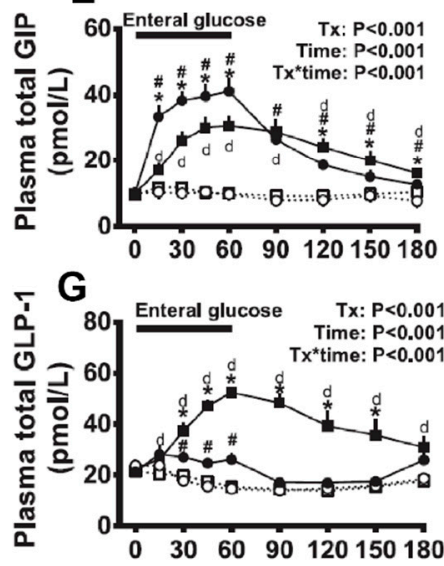

Subjects with T2DM
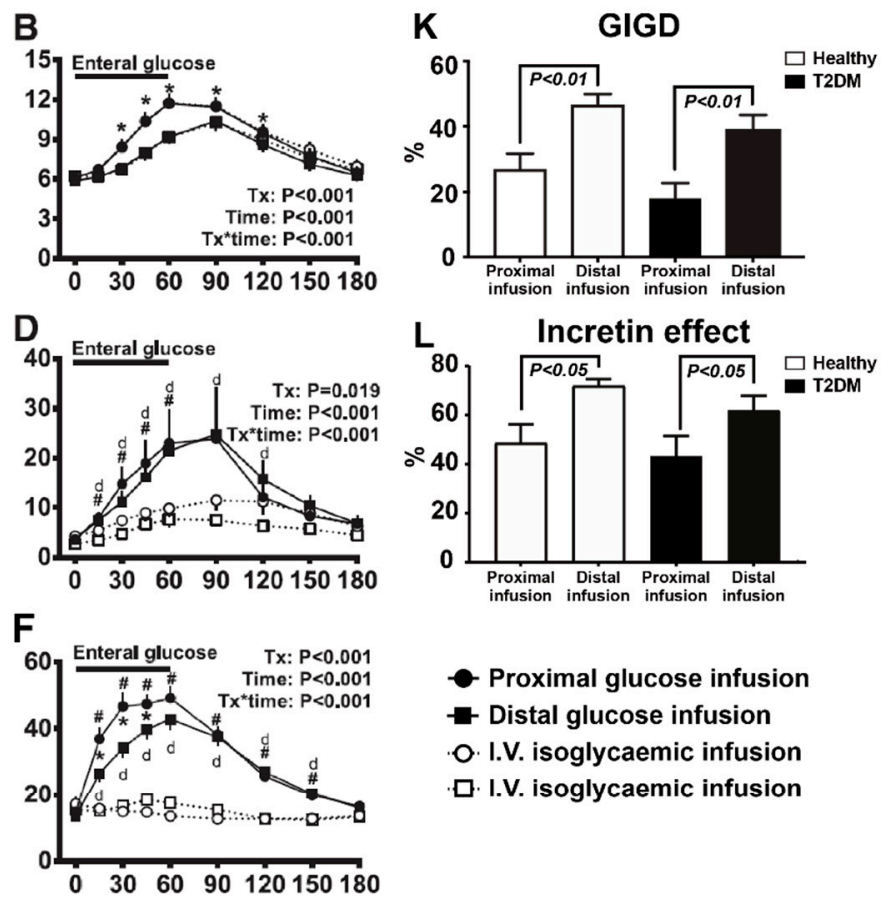

- Proximal glucose infusion

- Distal glucose infusion

O. I.V. isoglycaemic infusion

$\square$ I.V. isoglycaemic infusion

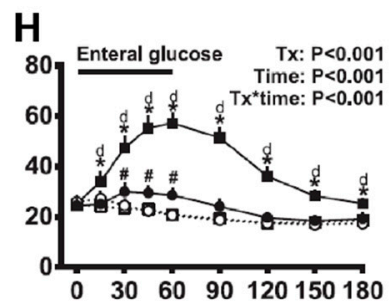

Figure 3. Comparative effects of proximal and distal small intestinal glucose exposure on glycaemia, incretin hormone secretion, and the incretin effect in both healthy individuals and patients with type 2 diabetes (T2DM) $(n=10$ each). (A,B) Blood glucose levels, (C,D) plasma insulin, (E,F) plasma total glucose-dependent insulinotropic polypeptide (GIP), $(\mathbf{G}, \mathbf{H})$ plasma total glucagon-like peptide 1 (GLP-1), (K) Gastrointestinal-mediated glucose disposal (GIGD), and (L) Incretin effect. ${ }^{*} p<0.05$ for proximal vs. distal enteral glucose infusion; $\# p<0.05$ for proximal enteral vs. corresponding i.v. glycaemic glucose infusion; $\mathrm{d} p<0.05$ for distal enteral vs. corresponding i.v. glycaemic glucose infusion. Data are mean \pm SEM. (Figures are adapted from reference [137], with permission from Diabetes Care, 2019).

\section{Summary}

The gastrointestinal tract serves not only as the site of nutrient digestion and absorption but also as an endocrine organ secreting a variety of gastrointestinal hormones as a result of the complex interaction between ingested nutrients, bioactive compounds and EECs to regulate postprandial glucose metabolism and energy intake. Given the major difference in the distribution of EECs between the upper and lower gut, the load and delivery of nutrients, as well as the digestive processes in the gastrointestinal tract, have major implications on how these EECs are stimulated. Exposure of the upper gut to nutrients is associated with predominantly GIP and CCK release, whereas increasing the delivery of nutrients to the distal small intestine and colon is associated with augmented secretion of GLP-1 and PPY. These distal gut hormones appear more potent in mediating postprandial glucose metabolism and suppressing energy intake than those secreted from the proximal gut. Accordingly, the distal gut is becoming an appealing target for the management of T2DM and obesity, using nutritional, pharmacological or surgical approaches to increase its exposure to nutrients and other 
bioactive compounds. Future development in this area is likely to yield novel therapies for T2DM and obesity of high efficacy without the need for surgical procedures.

Author Contributions: C.X., K.L.J., C.K.R. and T.W. were all involved in the conception, design and writing of the manuscript. All authors have read and agreed to the published version of the manuscript.

Funding: The authors' work in this area is supported by the Australia National Health and Medical Research Council (NHMRC). C.X. is supported by a postgraduate scholarship from the China Scholarship Council. K.L.J. is supported by a University of Adelaide William T Southcott Research Fellowship. T.W. is supported by a Mid-Career Fellowship from The Hospital Research Foundation.

Acknowledgments: The Centre of Research Excellence (CRE) in Translating Nutritional Science to Good Health has been supported by The Hospital Research Foundation.

Conflicts of Interest: The authors declare no conflict of interest.

\section{References}

1. Steinert, R.E.; Feinle-Bisset, C.; Asarian, L.; Horowitz, M.; Beglinger, C.; Geary, N. Ghrelin, CCK, GLP-1, and PYY(3-36): Secretory controls and physiological roles in eating and glycemia in health, obesity, and after RYGB. Physiol. Rev. 2017, 97, 411-463. [CrossRef] [PubMed]

2. Gribble, F.M.; Reimann, F. Function and mechanisms of enteroendocrine cells and gut hormones in metabolism. Nat. Rev. Endocrinol. 2019, 15, 226-237. [CrossRef] [PubMed]

3. Phillips, L.K.; Deane, A.M.; Jones, K.L.; Rayner, C.K.; Horowitz, M. Gastric emptying and glycaemia in health and diabetes mellitus. Nat. Rev. Endocrinol. 2015, 11, 112-128. [CrossRef] [PubMed]

4. Iqbal, J.; Hussain, M.M. Intestinal lipid absorption. Am. J. Physiol. Endocrinol. Metab. 2009, 296, E1183-E1194. [CrossRef] [PubMed]

5. Erickson, R.H.; Kim, Y.S. Digestion and absorption of dietary protein. Annu. Rev. Med. 1990, 41, $133-139$. [CrossRef]

6. Gray, G.M. Carbohydrate digestion and absorption. Role of the small intestine. N. Engl. J. Med. 1975, 292, 1225-1230. [CrossRef]

7. Song, P.; Onishi, A.; Koepsell, H.; Vallon, V. Sodium glucose cotransporter SGLT1 as a therapeutic target in diabetes mellitus. Expert Opin. Ther. Targets 2016, 20, 1109-1125. [CrossRef]

8. Wright, E.M.; Hirayama, B.A.; Loo, D.F. Active sugar transport in health and disease. J. Intern. Med. 2007, 261, 32-43. [CrossRef]

9. Balen, D.; Ljubojevic, M.; Breljak, D.; Brzica, H.; Zlender, V.; Koepsell, H.; Sabolic, I. Revised immunolocalization of the Na+-D-glucose cotransporter SGLT1 in rat organs with an improved antibody. Am. J. Physiol. Cell Physiol. 2008, 295, C475-C489. [CrossRef]

10. Thazhath, S.S.; Wu, T.; Young, R.L.; Horowitz, M.; Rayner, C.K. Glucose absorption in small intestinal diseases. Expert Rev. Gastroenterol. Hepatol. 2014, 8, 301-312. [CrossRef]

11. Gouyon, F.; Caillaud, L.; Carriere, V.; Klein, C.; Dalet, V.; Citadelle, D.; Kellett, G.L.; Thorens, B.; Leturque, A.; Brot-Laroche, E. Simple-sugar meals target GLUT2 at enterocyte apical membranes to improve sugar absorption: A study in GLUT2-null mice. J. Physiol. 2003, 552, 823-832. [CrossRef] [PubMed]

12. Davidson, N.O.; Hausman, A.M.; Ifkovits, C.A.; Buse, J.B.; Gould, G.W.; Burant, C.F.; Bell, G.I. Human intestinal glucose transporter expression and localization of GLUT5. Am. J. Physiol. 1992, 262, C795-C800. [CrossRef] [PubMed]

13. Abumrad, N.A.; Davidson, N.O. Role of the gut in lipid homeostasis. Physiol. Rev. 2012, 92, 1061-1085. [CrossRef] [PubMed]

14. Paalvast, Y.; de Boer, J.F.; Groen, A.K. Developments in intestinal cholesterol transport and triglyceride absorption. Curr. Opin. Lipidol. 2017, 28, 248-254. [CrossRef]

15. Carter, D.; Howlett, H.C.; Wiernsperger, N.F.; Bailey, C.J. Differential effects of metformin on bile salt absorption from the jejunum and ileum. Diabetes Obes. Metab. 2003, 5, 120-125. [CrossRef]

16. Broer, S. Amino acid transport across mammalian intestinal and renal epithelia. Physiol. Rev. 2008, 88, 249-286. [CrossRef]

17. Broer, S.; Fairweather, S.J. Amino acid transport across the mammalian intestine. Compr. Physiol. 2018, 9, 343-373. [CrossRef] 
18. Daniel, H.; Zietek, T. Taste and move: Glucose and peptide transporters in the gastrointestinal tract. Exp. Physiol. 2015, 100, 1441-1450. [CrossRef]

19. Gill, S.; Chater, P.I.; Wilcox, M.D.; Pearson, J.P.; Brownlee, I.A. The impact of dietary fibres on the physiological processes of the large intestine. Bioact. Carbohydr. Diet. Fibre 2018, 16, 62-74. [CrossRef]

20. Scott, K.P.; Gratz, S.W.; Sheridan, P.O.; Flint, H.J.; Duncan, S.H. The influence of diet on the gut microbiota. Pharm. Res. 2013, 69, 52-60. [CrossRef]

21. Topping, D.L.; Clifton, P.M. Short-chain fatty acids and human colonic function: Roles of resistant starch and nonstarch polysaccharides. Physiol. Rev. 2001, 81, 1031-1064. [CrossRef] [PubMed]

22. Kreuch, D.; Keating, D.J.; Wu, T.; Horowitz, M.; Rayner, C.K.; Young, R.L. Gut mechanisms linking intestinal sweet sensing to glycemic control. Front. Endocrinol. (Lausanne) 2018, 9, 741. [CrossRef]

23. Wu, T.; Bound, M.J.; Standfield, S.D.; Bellon, M.; Young, R.L.; Jones, K.L.; Horowitz, M.; Rayner, C.K. Artificial sweeteners have no effect on gastric emptying, glucagon-like peptide-1, or glycemia after oral glucose in healthy humans. Diabetes Care 2013, 36, e202-e203. [CrossRef] [PubMed]

24. Jang, H.J.; Kokrashvili, Z.; Theodorakis, M.J.; Carlson, O.D.; Kim, B.J.; Zhou, J.; Kim, H.H.; Xu, X.; Chan, S.L.; Juhaszova, M.; et al. Gut-expressed gustducin and taste receptors regulate secretion of glucagon-like peptide-1. Proc. Natl. Acad. Sci. USA 2007, 104, 15069-15074. [CrossRef] [PubMed]

25. Mace, O.J.; Schindler, M.; Patel, S. The regulation of K- and L-cell activity by GLUT2 and the calcium-sensing receptor CasR in rat small intestine. J. Physiol. 2012, 590, 2917-2936. [CrossRef]

26. Gorboulev, V.; Schurmann, A.; Vallon, V.; Kipp, H.; Jaschke, A.; Klessen, D.; Friedrich, A.; Scherneck, S.; Rieg, T.; Cunard, R.; et al. Na(+)-D-glucose cotransporter SGLT1 is pivotal for intestinal glucose absorption and glucose-dependent incretin secretion. Diabetes 2012, 61, 187-196. [CrossRef]

27. Wu, T.; Zhao, B.R.; Bound, M.J.; Checklin, H.L.; Bellon, M.; Little, T.J.; Young, R.L.; Jones, K.L.; Horowitz, M.; Rayner, C.K. Effects of different sweet preloads on incretin hormone secretion, gastric emptying, and postprandial glycemia in healthy humans. Am. J. Clin. Nutr. 2012, 95, 78-83. [CrossRef]

28. Beglinger, S.; Drewe, J.; Schirra, J.; Goke, B.; D’Amato, M.; Beglinger, C. Role of fat hydrolysis in regulating glucagon-like Peptide-1 secretion. J. Clin. Endocrinol. Metab. 2010, 95, 879-886. [CrossRef]

29. Kuo, P.; Stevens, J.E.; Russo, A.; Maddox, A.; Wishart, J.M.; Jones, K.L.; Greville, H.; Hetzel, D.; Chapman, I.; Horowitz, M.; et al. Gastric emptying, incretin hormone secretion, and postprandial glycemia in cystic fibrosis-effects of pancreatic enzyme supplementation. J. Clin. Endocrinol. Metab. 2011, 96, E851-E855. [CrossRef]

30. Perano, S.J.; Couper, J.J.; Horowitz, M.; Martin, A.J.; Kritas, S.; Sullivan, T.; Rayner, C.K. Pancreatic enzyme supplementation improves the incretin hormone response and attenuates postprandial glycemia in adolescents with cystic fibrosis: A randomized crossover trial. J. Clin. Endocrinol. Metab. 2014, 99, 2486-2493. [CrossRef]

31. Edfalk, S.; Steneberg, P.; Edlund, H. Gpr40 is expressed in enteroendocrine cells and mediates free fatty acid stimulation of incretin secretion. Diabetes 2008, 57, 2280-2287. [CrossRef] [PubMed]

32. Lauffer, L.M.; Iakoubov, R.; Brubaker, P.L. GPR119 is essential for oleoylethanolamide-induced glucagon-like peptide-1 secretion from the intestinal enteroendocrine L-cell. Diabetes 2009, 58, 1058-1066. [CrossRef] [PubMed]

33. Sankoda, A.; Harada, N.; Iwasaki, K.; Yamane, S.; Murata, Y.; Shibue, K.; Thewjitcharoen, Y.; Suzuki, K.; Harada, T.; Kanemaru, Y.; et al. Long-chain free fatty acid receptor GPR120 mediates oil-induced GIP secretion through CCK in male mice. Endocrinology 2017, 158, 1172-1180. [CrossRef] [PubMed]

34. Poreba, M.A.; Dong, C.X.; Li, S.K.; Stahl, A.; Miner, J.H.; Brubaker, P.L. Role of fatty acid transport protein 4 in oleic acid-induced glucagon-like peptide- 1 secretion from murine intestinal L cells. Am. J. Physiol. Endocrinol. Metab. 2012, 303, E899-E907. [CrossRef]

35. Sundaresan, S.; Shahid, R.; Riehl, T.E.; Chandra, R.; Nassir, F.; Stenson, W.F.; Liddle, R.A.; Abumrad, N.A. CD36-dependent signaling mediates fatty acid-induced gut release of secretin and cholecystokinin. FASEB J. 2013, 27, 1191-1202. [CrossRef]

36. Pais, R.; Gribble, F.M.; Reimann, F. Signalling pathways involved in the detection of peptones by murine small intestinal enteroendocrine L-cells. Peptides 2016, 77, 9-15. [CrossRef]

37. Jiang, Y.; Rose, A.J.; Sijmonsma, T.P.; Broer, A.; Pfenninger, A.; Herzig, S.; Schmoll, D.; Broer, S. Mice lacking neutral amino acid transporter B(0)AT1 (Slc6a19) have elevated levels of FGF21 and GLP-1 and improved glycaemic control. Mol. Metab. 2015, 4, 406-417. [CrossRef] 
38. Clemmensen, C.; Jorgensen, C.V.; Smajilovic, S.; Brauner-Osborne, H. Robust GLP-1 secretion by basic L-amino acids does not require the GPRC6A receptor. Diabetes Obes. Metab. 2017, 19, 599-603. [CrossRef]

39. Trabelsi, M.S.; Daoudi, M.; Prawitt, J.; Ducastel, S.; Touche, V.; Sayin, S.I.; Perino, A.; Brighton, C.A.; Sebti, Y.; Kluza, J.; et al. Farnesoid X receptor inhibits glucagon-like peptide-1 production by enteroendocrine $\mathrm{L}$ cells. Nat. Commun. 2015, 6, 7629. [CrossRef]

40. Thomas, C.; Gioiello, A.; Noriega, L.; Strehle, A.; Oury, J.; Rizzo, G.; Macchiarulo, A.; Yamamoto, H.; Mataki, C.; Pruzanski, M.; et al. TGR5-mediated bile acid sensing controls glucose homeostasis. Cell Metab. 2009, 10, 167-177. [CrossRef]

41. Kuhre, R.E.; Wewer Albrechtsen, N.J.; Larsen, O.; Jepsen, S.L.; Balk-Moller, E.; Andersen, D.B.; Deacon, C.F.; Schoonjans, K.; Reimann, F.; Gribble, F.M.; et al. Bile acids are important direct and indirect regulators of the secretion of appetite- and metabolism-regulating hormones from the gut and pancreas. Mol. Metab. 2018, 11, 84-95. [CrossRef]

42. Tough, I.R.; Schwartz, T.W.; Cox, H.M. Synthetic G protein-coupled bile acid receptor agonists and bile acids act via basolateral receptors in ileal and colonic mucosa. Neurogastroenterol. Motil. 2020, e13943. [CrossRef]

43. Xie, C.; Wang, X.; Young, R.L.; Horowitz, M.; Rayner, C.K.; Wu, T. Role of Intestinal Bitter Sensing in Enteroendocrine Hormone Secretion and Metabolic Control. Front. Endocrinol. (Lausanne) 2018, 9, 576. [CrossRef]

44. Wu, T.; Rayner, C.K.; Watson, L.E.; Jones, K.L.; Horowitz, M.; Little, T.J. Comparative effects of intraduodenal fat and glucose on the gut-incretin axis in healthy males. Peptides 2017, 95, 124-127. [CrossRef]

45. Ryan, A.T.; Luscombe-Marsh, N.D.; Saies, A.A.; Little, T.J.; Standfield, S.; Horowitz, M.; Feinle-Bisset, C. Effects of intraduodenal lipid and protein on gut motility and hormone release, glycemia, appetite, and energy intake in lean men. Am. J. Clin. Nutr. 2013, 98, 300-311. [CrossRef]

46. Jensen, C.Z.; Bojsen-Moller, K.N.; Svane, M.S.; Holst, L.M.; Hermansen, K.; Hartmann, B.; Wewer Albrechtsen, N.J.; Kuhre, R.E.; Kristiansen, V.B.; Rehfeld, J.F.; et al. Responses of gut and pancreatic hormones, bile acids, and fibroblast growth factor-21 differ to glucose, protein, and fat ingestion after gastric bypass surgery. Am. J. Physiol. Gastrointest. Liver Physiol. 2020, 318, G661-G672. [CrossRef]

47. Katsuma, S.; Hirasawa, A.; Tsujimoto, G. Bile acids promote glucagon-like peptide-1 secretion through TGR5 in a murine enteroendocrine cell line STC-1. Biochem. Biophys. Res. Commun. 2005, 329, 386-390. [CrossRef]

48. Andersen, A.; Lund, A.; Knop, F.K.; Vilsboll, T. Glucagon-like peptide 1 in health and disease. Nat. Rev. Endocrinol. 2018, 14, 390-403. [CrossRef]

49. Holst, J.J.; Albrechtsen, N.J.W.; Rosenkilde, M.M.; Deacon, C.F. Physiology of the incretin hormones, GIP and GLP-1-regulation of release and posttranslational modifications. Compr. Physiol. 2019, 9, 1339-1381. [CrossRef]

50. Wu, T.; Rayner, C.K.; Horowitz, M. Incretins. Handb. Exp. Pharm. 2016, 233, 137-171. [CrossRef]

51. Nauck, M.A.; Meier, J.J. Incretin hormones: Their role in health and disease. Diabetes Obes. Metab. 2018, 20 (Suppl. 1), 5-21. [CrossRef]

52. Hare, K.J.; Vilsboll, T.; Asmar, M.; Deacon, C.F.; Knop, F.K.; Holst, J.J. The glucagonostatic and insulinotropic effects of glucagon-like peptide 1 contribute equally to its glucose-lowering action. Diabetes 2010, 59, 1765-1770. [CrossRef] [PubMed]

53. Maida, A.; Hansotia, T.; Longuet, C.; Seino, Y.; Drucker, D.J. Differential importance of glucose-dependent insulinotropic polypeptide vs glucagon-like peptide 1 receptor signaling for beta cell survival in mice. Gastroenterology 2009, 137, 2146-2157. [CrossRef]

54. Seghieri, M.; Rebelos, E.; Gastaldelli, A.; Astiarraga, B.D.; Casolaro, A.; Barsotti, E.; Pocai, A.; Nauck, M.; Muscelli, E.; Ferrannini, E. Direct effect of GLP-1 infusion on endogenous glucose production in humans. Diabetologia 2013, 56, 156-161. [CrossRef]

55. Nauck, M.A.; Niedereichholz, U.; Ettler, R.; Holst, J.J.; Orskov, C.; Ritzel, R.; Schmiegel, W.H. Glucagon-like peptide 1 inhibition of gastric emptying outweighs its insulinotropic effects in healthy humans. Am. J. Physiol. 1997, 273, E981-E988. [CrossRef]

56. Little, T.J.; Pilichiewicz, A.N.; Russo, A.; Phillips, L.; Jones, K.L.; Nauck, M.A.; Wishart, J.; Horowitz, M.; Feinle-Bisset, C. Effects of intravenous glucagon-like peptide-1 on gastric emptying and intragastric distribution in healthy subjects: Relationships with postprandial glycemic and insulinemic responses. J. Clin. Endocrinol. Metab. 2006, 91, 1916-1923. [CrossRef] 
57. Jones, K.L.; Rigda, R.S.; Buttfield, M.D.M.; Hatzinikolas, S.; Pham, H.T.; Marathe, C.S.; Wu, T.; Lange, K.; Trahair, L.G.; Rayner, C.K.; et al. Effects of lixisenatide on postprandial blood pressure, gastric emptying and glycaemia in healthy people and people with type 2 diabetes. Diabetes Obes. Metab. 2019, 21, 1158-1167. [CrossRef]

58. Deane, A.M.; Nguyen, N.Q.; Stevens, J.E.; Fraser, R.J.; Holloway, R.H.; Besanko, L.K.; Burgstad, C.; Jones, K.L.; Chapman, M.J.; Rayner, C.K.; et al. Endogenous glucagon-like peptide-1 slows gastric emptying in healthy subjects, attenuating postprandial glycemia. J. Clin. Endocrinol. Metab. 2010, 95, 215-221. [CrossRef]

59. Lorenz, M.; Pfeiffer, C.; Steinstrasser, A.; Becker, R.H.; Rutten, H.; Ruus, P.; Horowitz, M. Effects of lixisenatide once daily on gastric emptying in type 2 diabetes-relationship to postprandial glycemia. Regul. Pept. 2013, 185, 1-8. [CrossRef]

60. Stevens, J.E.; Buttfield, M.; Wu, T.; Hatzinikolas, S.; Pham, H.; Lange, K.; Rayner, C.K.; Horowitz, M.; Jones, K.L. Effects of sitagliptin on gastric emptying of, and the glycaemic and blood pressure responses to, a carbohydrate meal in type 2 diabetes. Diabetes Obes. Metab. 2020, 22, 51-58. [CrossRef]

61. DeFronzo, R.A.; Okerson, T.; Viswanathan, P.; Guan, X.; Holcombe, J.H.; MacConell, L. Effects of exenatide versus sitagliptin on postprandial glucose, insulin and glucagon secretion, gastric emptying, and caloric intake: A randomized, cross-over study. Curr. Med. Res. Opin. 2008, 24, 2943-2952. [CrossRef] [PubMed]

62. Hsieh, J.; Longuet, C.; Baker, C.L.; Qin, B.; Federico, L.M.; Drucker, D.J.; Adeli, K. The glucagon-like peptide 1 receptor is essential for postprandial lipoprotein synthesis and secretion in hamsters and mice. Diabetologia 2010, 53, 552-561. [CrossRef] [PubMed]

63. Qin, X.; Shen, H.; Liu, M.; Yang, Q.; Zheng, S.; Sabo, M.; D'Alessio, D.A.; Tso, P. GLP-1 reduces intestinal lymph flow, triglyceride absorption, and apolipoprotein production in rats. Am. J. Physiol. Gastrointest. Liver Physiol. 2005, 288, G943-G949. [CrossRef]

64. Xiao, C.; Bandsma, R.H.; Dash, S.; Szeto, L.; Lewis, G.F. Exenatide, a glucagon-like peptide-1 receptor agonist, acutely inhibits intestinal lipoprotein production in healthy humans. Arter. Thromb. Vasc. Biol. 2012, 32, 1513-1519. [CrossRef]

65. Xiao, C.; Dash, S.; Morgantini, C.; Patterson, B.W.; Lewis, G.F. Sitagliptin, a DPP-4 inhibitor, acutely inhibits intestinal lipoprotein particle secretion in healthy humans. Diabetes 2014, 63, 2394-2401. [CrossRef] [PubMed]

66. Hjerpsted, J.B.; Flint, A.; Brooks, A.; Axelsen, M.B.; Kvist, T.; Blundell, J. Semaglutide improves postprandial glucose and lipid metabolism, and delays first-hour gastric emptying in subjects with obesity. Diabetes Obes. Metab. 2018, 20, 610-619. [CrossRef]

67. Holst, J.J. The physiology of glucagon-like peptide 1. Physiol. Rev. 2007, 87, 1409-1439. [CrossRef]

68. Plamboeck, A.; Veedfald, S.; Deacon, C.F.; Hartmann, B.; Wettergren, A.; Svendsen, L.B.; Meisner, S.; Hovendal, C.; Vilsboll, T.; Knop, F.K.; et al. The effect of exogenous GLP-1 on food intake is lost in male truncally vagotomized subjects with pyloroplasty. Am. J. Physiol. Gastrointest. Liver Physiol. 2013, 304, G1117-G1127. [CrossRef]

69. Krieger, J.P.; Arnold, M.; Pettersen, K.G.; Lossel, P.; Langhans, W.; Lee, S.J. Knockdown of GLP-1 receptors in vagal afferents affects normal food intake and glycemia. Diabetes 2016, 65, 34-43. [CrossRef]

70. Turton, M.D.; O'Shea, D.; Gunn, I.; Beak, S.A.; Edwards, C.M.; Meeran, K.; Choi, S.J.; Taylor, G.M.; Heath, M.M.; Lambert, P.D.; et al. A role for glucagon-like peptide-1 in the central regulation of feeding. Nature 1996, 379, 69-72. [CrossRef]

71. ten Kulve, J.S.; Veltman, D.J.; van Bloemendaal, L.; Barkhof, F.; Deacon, C.F.; Holst, J.J.; Konrad, R.J.; Sloan, J.H.; Drent, M.L.; Diamant, M.; et al. Endogenous GLP-1 mediates postprandial reductions in activation in central reward and satiety areas in patients with type 2 diabetes. Diabetologia 2015, 58, 2688-2698. [CrossRef] [PubMed]

72. Pratley, R.; Amod, A.; Hoff, S.T.; Kadowaki, T.; Lingvay, I.; Nauck, M.; Pedersen, K.B.; Saugstrup, T.; Meier, J.J. Oral semaglutide versus subcutaneous liraglutide and placebo in type 2 diabetes (PIONEER 4): A randomised, double-blind, phase 3a trial. Lancet 2019, 394, 39-50. [CrossRef]

73. Xu, F.; Lin, B.; Zheng, X.; Chen, Z.; Cao, H.; Xu, H.; Liang, H.; Weng, J. GLP-1 receptor agonist promotes brown remodelling in mouse white adipose tissue through SIRT1. Diabetologia 2016, 59, 1059-1069. [CrossRef] [PubMed]

74. Lynch, L.; Hogan, A.E.; Duquette, D.; Lester, C.; Banks, A.; LeClair, K.; Cohen, D.E.; Ghosh, A.; Lu, B.; Corrigan, M.; et al. iNKT cells induce FGF21 for thermogenesis and are required for maximal weight loss in GLP1 therapy. Cell Metab. 2016, 24, 510-519. [CrossRef] 
75. Beiroa, D.; Imbernon, M.; Gallego, R.; Senra, A.; Herranz, D.; Villarroya, F.; Serrano, M.; Ferno, J.; Salvador, J.; Escalada, J.; et al. GLP-1 agonism stimulates brown adipose tissue thermogenesis and browning through hypothalamic AMPK. Diabetes 2014, 63, 3346-3358. [CrossRef]

76. Tomas, E.; Stanojevic, V.; McManus, K.; Khatri, A.; Everill, P.; Bachovchin, W.W.; Habener, J.F. GLP-1(32-36)amide pentapeptide increases basal energy expenditure and inhibits weight gain in obese mice. Diabetes 2015, 64, 2409-2419. [CrossRef]

77. Goldsmith, F.; Keenan, M.J.; Raggio, A.M.; Ye, X.; Hao, Z.; Durham, H.; Geaghan, J.; Jia, W.P.; Martin, R.J.; Ye, J.P. Induction of energy expenditure by sitagliptin is dependent on GLP-1 receptor. PLoS ONE 2015, 10, e0126177. [CrossRef]

78. Fukuda-Tsuru, S.; Kakimoto, T.; Utsumi, H.; Kiuchi, S.; Ishii, S. The novel dipeptidyl peptidase-4 inhibitor teneligliptin prevents high-fat diet-induced obesity accompanied with increased energy expenditure in mice. Eur. J. Pharm. 2014, 723, 207-215. [CrossRef]

79. Maciel, M.G.; Beserra, B.T.S.; Oliveira, F.C.B.; Ribeiro, C.M.; Coelho, M.S.; Neves, F.A.R.; Amato, A.A. The effect of glucagon-like peptide 1 and glucagon-like peptide 1 receptor agonists on energy expenditure: A systematic review and meta-analysis. Diabetes Res. Clin. Pr. 2018, 142, 222-235. [CrossRef]

80. Heruc, G.A.; Horowitz, M.; Deacon, C.F.; Feinle-Bisset, C.; Rayner, C.K.; Luscombe-Marsh, N.; Little, T.J. Effects of dipeptidyl peptidase IV inhibition on glycemic, gut hormone, triglyceride, energy expenditure, and energy intake responses to fat in healthy males. Am. J. Physiol. Endocrinol. Metab. 2014, 307, E830-E837. [CrossRef]

81. Xie, C.; Wang, X.; Jones, K.L.; Horowitz, M.; Sun, Z.; Little, T.J.; Rayner, C.K.; Wu, T. Role of endogenous glucagon-like peptide-1 enhanced by vildagliptin in the glycaemic and energy expenditure responses to intraduodenal fat infusion in type 2 diabetes. Diabetes Obes. Metab. 2020, 22, 383-392. [CrossRef] [PubMed]

82. Mortensen, K.; Christensen, L.L.; Holst, J.J.; Orskov, C. GLP-1 and GIP are colocalized in a subset of endocrine cells in the small intestine. Regul. Pept. 2003, 114, 189-196. [CrossRef]

83. Svendsen, B.; Pedersen, J.; Albrechtsen, N.J.; Hartmann, B.; Torang, S.; Rehfeld, J.F.; Poulsen, S.S.; Holst, J.J. An analysis of cosecretion and coexpression of gut hormones from male rat proximal and distal small intestine. Endocrinology 2015, 156, 847-857. [CrossRef] [PubMed]

84. Wu, T.; Rayner, C.K.; Jones, K.; Horowitz, M. Dietary effects on incretin hormone secretion. Vitam Horm 2010, 84, 81-110. [CrossRef] [PubMed]

85. Holst, J.J.; Gromada, J. Role of incretin hormones in the regulation of insulin secretion in diabetic and nondiabetic humans. Am. J. Physiol. Endocrinol. Metab. 2004, 287, E199-E206. [CrossRef] [PubMed]

86. Mentis, N.; Vardarli, I.; Köthe, L.D.; Holst, J.J.; Deacon, C.F.; Theodorakis, M.; Meier, J.J.; Nauck, M.A. GIP does not potentiate the antidiabetic effects of GLP-1 in hyperglycemic patients with type 2 diabetes. Diabetes 2011, 60, 1270-1276. [CrossRef] [PubMed]

87. Christensen, M.; Calanna, S.; Sparre-Ulrich, A.H.; Kristensen, P.L.; Rosenkilde, M.M.; Faber, J.; Purrello, F.; van Hall, G.; Holst, J.J.; Vilsboll, T.; et al. Glucose-dependent insulinotropic polypeptide augments glucagon responses to hypoglycemia in type 1 diabetes. Diabetes 2015, 64, 72-78. [CrossRef]

88. Bergmann, N.C.; Lund, A.; Gasbjerg, L.S.; Meessen, E.C.E.; Andersen, M.M.; Bergmann, S.; Hartmann, B.; Holst, J.J.; Jessen, L.; Christensen, M.B.; et al. Effects of combined GIP and GLP-1 infusion on energy intake, appetite and energy expenditure in overweight/obese individuals: A randomised, crossover study. Diabetologia 2019, 62, 665-675. [CrossRef]

89. Meier, J.J.; Goetze, O.; Anstipp, J.; Hagemann, D.; Holst, J.J.; Schmidt, W.E.; Gallwitz, B.; Nauck, M.A. Gastric inhibitory polypeptide does not inhibit gastric emptying in humans. Am. J. Physiol. Endocrinol. Metab. 2004, 286, E621-E625. [CrossRef]

90. Miyawaki, K.; Yamada, Y.; Ban, N.; Ihara, Y.; Tsukiyama, K.; Zhou, H.; Fujimoto, S.; Oku, A.; Tsuda, K.; Toyokuni, S.; et al. Inhibition of gastric inhibitory polypeptide signaling prevents obesity. Nat. Med. 2002, 8, 738-742. [CrossRef]

91. Naitoh, R.; Miyawaki, K.; Harada, N.; Mizunoya, W.; Toyoda, K.; Fushiki, T.; Yamada, Y.; Seino, Y.; Inagaki, N. Inhibition of GIP signaling modulates adiponectin levels under high-fat diet in mice. Biochem. Biophys. Res. Commun. 2008, 376, 21-25. [CrossRef] [PubMed]

92. Zhou, H.; Yamada, Y.; Tsukiyama, K.; Miyawaki, K.; Hosokawa, M.; Nagashima, K.; Toyoda, K.; Naitoh, R.; Mizunoya, W.; Fushiki, T.; et al. Gastric inhibitory polypeptide modulates adiposity and fat oxidation under diminished insulin action. Biochem. Biophys. Res. Commun. 2005, 335, 937-942. [CrossRef] [PubMed] 
93. Hansotia, T.; Maida, A.; Flock, G.; Yamada, Y.; Tsukiyama, K.; Seino, Y.; Drucker, D.J. Extrapancreatic incretin receptors modulate glucose homeostasis, body weight, and energy expenditure. J. Clin. Investig. 2007, 117, 143-152. [CrossRef] [PubMed]

94. Boylan, M.O.; Glazebrook, P.A.; Tatalovic, M.; Wolfe, M.M. Gastric inhibitory polypeptide immunoneutralization attenuates development of obesity in mice. Am. J. Physiol. Endocrinol. Metab. 2015, 309, E1008-E1018. [CrossRef]

95. Asmar, M.; Asmar, A.; Simonsen, L.; Gasbjerg, L.S.; Sparre-Ulrich, A.H.; Rosenkilde, M.M.; Hartmann, B.; Dela, F.; Holst, J.J.; Bulow, J. The gluco- and liporegulatory and vasodilatory effects of glucose-dependent insulinotropic polypeptide (GIP) are abolished by an antagonist of the human GIP receptor. Diabetes 2017, 66, 2363-2371. [CrossRef]

96. Frias, J.P.; Nauck, M.A.; Van, J.; Kutner, M.E.; Cui, X.; Benson, C.; Urva, S.; Gimeno, R.E.; Milicevic, Z.; Robins, D.; et al. Efficacy and safety of LY3298176, a novel dual GIP and GLP-1 receptor agonist, in patients with type 2 diabetes: A randomised, placebo-controlled and active comparator-controlled phase 2 trial. Lancet 2018, 392, 2180-2193. [CrossRef]

97. Frias, J.P.; Bastyr, E.J., 3rd; Vignati, L.; Tschop, M.H.; Schmitt, C.; Owen, K.; Christensen, R.H.; DiMarchi, R.D. The sustained effects of a dual GIP/GLP-1 receptor agonist, NNC0090-2746, in patients with type 2 diabetes. Cell Metab. 2017, 26, 343-352. [CrossRef]

98. Bergmann, N.C.; Gasbjerg, L.S.; Heimburger, S.M.; Krogh, L.S.L.; Dela, F.; Hartmann, B.; Holst, J.J.; Jessen, L.; Christensen, M.B.; Vilsboll, T.; et al. No acute effects of exogenous glucose-dependent insulinotropic polypeptide on energy intake, appetite, or energy expenditure when added to treatment with a long-acting glucagon-like peptide 1 receptor agonist in men with type 2 diabetes. Diabetes Care 2020, 43, 588-596. [CrossRef]

99. Sykaras, A.G.; Demenis, C.; Cheng, L.; Pisitkun, T.; McLaughlin, J.T.; Fenton, R.A.; Smith, C.P. Duodenal CCK cells from male mice express multiple hormones including ghrelin. Endocrinology 2014, 155, 3339-3351. [CrossRef]

100. Little, T.J.; Doran, S.; Meyer, J.H.; Smout, A.J.; O’Donovan, D.G.; Wu, K.L.; Jones, K.L.; Wishart, J.; Rayner, C.K.; Horowitz, M.; et al. The release of GLP-1 and ghrelin, but not GIP and CCK, by glucose is dependent upon the length of small intestine exposed. Am. J. Physiol. Endocrinol. Metab. 2006, 291, E647-E655. [CrossRef]

101. Liddle, R.A.; Rushakoff, R.J.; Morita, E.T.; Beccaria, L.; Carter, J.D.; Goldfine, I.D. Physiological role for cholecystokinin in reducing postprandial hyperglycemia in humans. J. Clin. Investig. 1988, 81, 1675-1681. [CrossRef] [PubMed]

102. Ahren, B.; Holst, J.J.; Efendic, S. Antidiabetogenic action of cholecystokinin-8 in type 2 diabetes. J. Clin. Endocrinol. Metab. 2000, 85, 1043-1048. [CrossRef] [PubMed]

103. Horowitz, M.; Harding, P.E.; Maddox, A.F.; Wishart, J.M.; Akkermans, L.M.; Chatterton, B.E.; Shearman, D.J. Gastric and oesophageal emptying in patients with type 2 (non-insulin-dependent) diabetes mellitus. Diabetologia 1989, 32, 151-159. [CrossRef] [PubMed]

104. Reidelberger, R.D.; Hernandez, J.; Fritzsch, B.; Hulce, M. Abdominal vagal mediation of the satiety effects of CCK in rats. Am. J. Physiol. Regul. Integr. Comp. Physiol. 2004, 286, R1005-R1012. [CrossRef] [PubMed]

105. MacIntosh, C.G.; Morley, J.E.; Wishart, J.; Morris, H.; Jansen, J.B.; Horowitz, M.; Chapman, I.M. Effect of exogenous cholecystokinin (CCK)-8 on food intake and plasma CCK, leptin, and insulin concentrations in older and young adults: Evidence for increased CCK activity as a cause of the anorexia of aging. J. Clin. Endocrinol. Metab. 2001, 86, 5830-5837. [CrossRef] [PubMed]

106. Brennan, I.M.; Feltrin, K.L.; Horowitz, M.; Smout, A.J.; Meyer, J.H.; Wishart, J.; Feinle-Bisset, C. Evaluation of interactions between CCK and GLP-1 in their effects on appetite, energy intake, and antropyloroduodenal motility in healthy men. Am. J. Physiol. Regul. Integr. Comp. Physiol. 2005, 288, R1477-R1485. [CrossRef]

107. Brennan, I.M.; Little, T.J.; Feltrin, K.L.; Smout, A.J.; Wishart, J.M.; Horowitz, M.; Feinle-Bisset, C. Dose-dependent effects of cholecystokinin-8 on antropyloroduodenal motility, gastrointestinal hormones, appetite, and energy intake in healthy men. Am. J. Physiol. Endocrinol. Metab. 2008, 295, E1487-E1494. [CrossRef]

108. Beglinger, C.; Degen, L.; Matzinger, D.; D’Amato, M.; Drewe, J. Loxiglumide, a CCK-A receptor antagonist, stimulates calorie intake and hunger feelings in humans. Am. J. Physiol. Regul. Integr. Comp. Physiol. 2001, 280, R1149-R1154. [CrossRef] 
109. de Krom, M.; van der Schouw, Y.T.; Hendriks, J.; Ophoff, R.A.; van Gils, C.H.; Stolk, R.P.; Grobbee, D.E.; Adan, R. Common genetic variations in CCK, leptin, and leptin receptor genes are associated with specific human eating patterns. Diabetes 2007, 56, 276-280. [CrossRef]

110. Lieverse, R.J.; Jansen, J.B.; Masclee, A.A.; Lamers, C.B. Satiety effects of a physiological dose of cholecystokinin in humans. Gut 1995, 36, 176-179. [CrossRef]

111. Habib, A.M.; Richards, P.; Rogers, G.J.; Reimann, F.; Gribble, F.M. Co-localisation and secretion of glucagon-like peptide 1 and peptide YY from primary cultured human L cells. Diabetologia 2013, 56, 1413-1416. [CrossRef] [PubMed]

112. Essah, P.A.; Levy, J.R.; Sistrun, S.N.; Kelly, S.M.; Nestler, J.E. Effect of macronutrient composition on postprandial peptide YY levels. J. Clin. Endocrinol. Metab. 2007, 92, 4052-4055. [CrossRef] [PubMed]

113. Brennan, I.M.; Luscombe-Marsh, N.D.; Seimon, R.V.; Otto, B.; Horowitz, M.; Wishart, J.M.; Feinle-Bisset, C. Effects of fat, protein, and carbohydrate and protein load on appetite, plasma cholecystokinin, peptide YY, and ghrelin, and energy intake in lean and obese men. Am. J. Physiol. Gastrointest. Liver Physiol. 2012, 303, G129-G140. [CrossRef] [PubMed]

114. Helou, N.; Obeid, O.; Azar, S.T.; Hwalla, N. Variation of postprandial PYY 3-36 response following ingestion of differing macronutrient meals in obese females. Ann. Nutr. Metab. 2008, 52, 188-195. [CrossRef] [PubMed]

115. Batterham, R.L.; Heffron, H.; Kapoor, S.; Chivers, J.E.; Chandarana, K.; Herzog, H.; Le Roux, C.W.; Thomas, E.L.; Bell, J.D.; Withers, D.J. Critical role for peptide YY in protein-mediated satiation and body-weight regulation. Cell Metab. 2006, 4, 223-233. [CrossRef]

116. Broberger, C.; Landry, M.; Wong, H.; Walsh, J.N.; Hokfelt, T. Subtypes Y1 and Y2 of the neuropeptide Y receptor are respectively expressed in pro-opiomelanocortin- and neuropeptide-Y-containing neurons of the rat hypothalamic arcuate nucleus. Neuroendocrinology 1997, 66, 393-408. [CrossRef]

117. Batterham, R.L.; Cowley, M.A.; Small, C.J.; Herzog, H.; Cohen, M.A.; Dakin, C.L.; Wren, A.M.; Brynes, A.E.; Low, M.J.; Ghatei, M.A.; et al. Gut hormone PYY3-36 physiologically inhibits food intake. Nature 2002, 418, 650-654. [CrossRef]

118. Abbott, C.R.; Small, C.J.; Kennedy, A.R.; Neary, N.M.; Sajedi, A.; Ghatei, M.A.; Bloom, S.R. Blockade of the neuropeptide $\mathrm{Y} Y 2$ receptor with the specific antagonist BIIE0246 attenuates the effect of endogenous and exogenous peptide YY(3-36) on food intake. Brain Res. 2005, 1043, 139-144. [CrossRef]

119. Guo, Y.; Ma, L.; Enriori, P.J.; Koska, J.; Franks, P.W.; Brookshire, T.; Cowley, M.A.; Salbe, A.D.; Delparigi, A.; Tataranni, P.A. Physiological evidence for the involvement of peptide $Y Y$ in the regulation of energy homeostasis in humans. Obesity (Silver Spring) 2006, 14, 1562-1570. [CrossRef]

120. Stoeckel, L.E.; Weller, R.E.; Giddings, M.; Cox, J.E. Peptide YY levels are associated with appetite suppression in response to long-chain fatty acids. Physiol. Behav. 2008, 93, 289-295. [CrossRef]

121. Degen, L.; Oesch, S.; Casanova, M.; Graf, S.; Ketterer, S.; Drewe, J.; Beglinger, C. Effect of peptide YY3-36 on food intake in humans. Gastroenterology 2005, 129, 1430-1436. [CrossRef] [PubMed]

122. le Roux, C.W.; Borg, C.M.; Murphy, K.G.; Vincent, R.P.; Ghatei, M.A.; Bloom, S.R. Supraphysiological doses of intravenous PYY3-36 cause nausea, but no additional reduction in food intake. Ann. Clin. Biochem. 2008, 45, 93-95. [CrossRef] [PubMed]

123. Rangwala, S.M.; D'Aquino, K.; Zhang, Y.M.; Bader, L.; Edwards, W.; Zheng, S.; Eckardt, A.; Lacombe, A.; Pick, R.; Moreno, V.; et al. A long-acting PYY3-36 analog mediates robust anorectic efficacy with minimal emesis in nonhuman primates. Cell Metab. 2019, 29, 837-843. [CrossRef] [PubMed]

124. Savage, A.P.; Adrian, T.E.; Carolan, G.; Chatterjee, V.K.; Bloom, S.R. Effects of peptide YY (PYY) on mouth to caecum intestinal transit time and on the rate of gastric emptying in healthy volunteers. Gut 1987, 28, 166-170. [CrossRef]

125. Chelikani, P.K.; Haver, A.C.; Reidelberger, R.D. Comparison of the inhibitory effects of PYY(3-36) and PYY(1-36) on gastric emptying in rats. Am. J. Physiol. Regul. Integr. Comp. Physiol. 2004, 287, R1064-R1070. [CrossRef]

126. Moran, T.H.; Smedh, U.; Kinzig, K.P.; Scott, K.A.; Knipp, S.; Ladenheim, E.E. Peptide YY(3-36) inhibits gastric emptying and produces acute reductions in food intake in rhesus monkeys. Am. J. Physiol. Regul. Integr. Comp. Physiol. 2005, 288, R384-R388. [CrossRef]

127. Witte, A.B.; Gryback, P.; Holst, J.J.; Hilsted, L.; Hellstrom, P.M.; Jacobsson, H.; Schmidt, P.T. Differential effect of PYY1-36 and PYY3-36 on gastric emptying in man. Regul. Pept. 2009, 158, 57-62. [CrossRef] 
128. Bottcher, G.; Ahren, B.; Lundquist, I.; Sundler, F. Peptide YY: Intrapancreatic localization and effects on insulin and glucagon secretion in the mouse. Pancreas 1989, 4, 282-288. [CrossRef]

129. Nieuwenhuizen, A.G.; Karlsson, S.; Fridolf, T.; Ahren, B. Mechanisms underlying the insulinostatic effect of peptide $\mathrm{YY}$ in mouse pancreatic islets. Diabetologia 1994, 37, 871-878. [CrossRef]

130. Lafferty, R.A.; Gault, V.A.; Flatt, P.R.; Irwin, N. Effects of 2 novel PYY(1-36) analogues, (P(3)L(31)P(34)) PYY(1-36) and PYY(1-36)(Lys(12)PAL), on pancreatic beta-cell function, growth, and survival. Clin. Med. Insights Endocrinol. Diabetes 2019, 12, 1179551419855626. [CrossRef]

131. Boey, D.; Heilbronn, L.; Sainsbury, A.; Laybutt, R.; Kriketos, A.; Herzog, H.; Campbell, L.V. Low serum PYY is linked to insulin resistance in first-degree relatives of subjects with type 2 diabetes. Neuropeptides 2006, 40, 317-324. [CrossRef] [PubMed]

132. Boey, D.; Lin, S.; Karl, T.; Baldock, P.; Lee, N.; Enriquez, R.; Couzens, M.; Slack, K.; Dallmann, R.; Sainsbury, A.; et al. Peptide YY ablation in mice leads to the development of hyperinsulinaemia and obesity. Diabetologia 2006, 49, 1360-1370. [CrossRef] [PubMed]

133. Ahrén, B.; Larsson, H. Peptide YY does not inhibit glucose-stimulated insulin secretion in humans. Eur. J. Endocrinol. 1996, 134, 362-365. [CrossRef] [PubMed]

134. Nguyen, N.Q.; Debreceni, T.L.; Burgess, J.E.; Bellon, M.; Wishart, J.; Standfield, S.; Malbert, C.H.; Horowitz, M. Impact of gastric emptying and small intestinal transit on blood glucose, intestinal hormones, glucose absorption in the morbidly obese. Int. J. Obes. (Lond) 2018, 42, 1556-1564. [CrossRef]

135. Duchman, S.M.; Ryan, A.J.; Schedl, H.P.; Summers, R.W.; Bleier, T.L.; Gisolfi, C.V. Upper limit for intestinal absorption of a dilute glucose solution in men at rest. Med. Sci. Sports Exerc. 1997, 29, 482-488. [CrossRef]

136. Yoshikawa, T.; Inoue, R.; Matsumoto, M.; Yajima, T.; Ushida, K.; Iwanaga, T. Comparative expression of hexose transporters (SGLT1, GLUT1, GLUT2 and GLUT5) throughout the mouse gastrointestinal tract. Histochem. Cell Biol. 2011, 135, 183-194. [CrossRef]

137. Zhang, X.; Young, R.L.; Bound, M.; Hu, S.; Jones, K.L.; Horowitz, M.; Rayner, C.K.; Wu, T. Comparative effects of proximal and distal small intestinal glucose exposure on glycemia, incretin hormone Ssecretion, and the incretin effect in health and type 2 diabetes. Diabetes Care 2019, 42, 520-528. [CrossRef]

138. Yan, S.; Sun, F.; Li, Z.; Xiang, J.; Ding, Y.; Lu, Z.; Tian, Y.; Chen, H.; Zhang, J.; Wang, Y.; et al. Reduction of intestinal electrogenic glucose absorption after duodenojejunal bypass in a mouse model. Obes. Surg. 2013, 23, 1361-1369. [CrossRef]

139. Jurowich, C.F.; Rikkala, P.R.; Thalheimer, A.; Wichelmann, C.; Seyfried, F.; Sander, V.; Kreissl, M.; Germer, C.T.; Koepsell, H.; Otto, C. Duodenal-jejunal bypass improves glycemia and decreases SGLT1-mediated glucose absorption in rats with streptozotocin-induced type 2 diabetes. Ann. Surg. 2013, 258, 89-97. [CrossRef]

140. de Jonge, C.; Rensen, S.S.; Verdam, F.J.; Vincent, R.P.; Bloom, S.R.; Buurman, W.A.; le Roux, C.W.; Schaper, N.C.; Bouvy, N.D.; Greve, J.W. Endoscopic duodenal-jejunal bypass liner rapidly improves type 2 diabetes. Obes. Surg. 2013, 23, 1354-1360. [CrossRef]

141. Koehestanie, P.; de Jonge, C.; Berends, F.J.; Janssen, I.M.; Bouvy, N.D.; Greve, J.W. The effect of the endoscopic duodenal-jejunal bypass liner on obesity and type 2 diabetes mellitus, a multicenter randomized controlled trial. Ann. Surg. 2014, 260, 984-992. [CrossRef] [PubMed]

142. Lobo, M.V.; Huerta, L.; Ruiz-Velasco, N.; Teixeiro, E.; de la Cueva, P.; Celdran, A.; Martin-Hidalgo, A.; Vega, M.A.; Bragado, R. Localization of the lipid receptors CD36 and CLA-1/SR-BI in the human gastrointestinal tract: Towards the identification of receptors mediating the intestinal absorption of dietary lipids. J. Histochem. Cytochem. 2001, 49, 1253-1260. [CrossRef]

143. Ockner, R.K.; Manning, J.A. Fatty acid-binding protein in small intestine. Identification, isolation, and evidence for its role in cellular fatty acid transport. J. Clin. Investig. 1974, 54, 326-338. [CrossRef]

144. Chen, M.; Yang, Y.; Braunstein, E.; Georgeson, K.E.; Harmon, C.M. Gut expression and regulation of FAT/CD36: Possible role in fatty acid transport in rat enterocytes. Am. J. Physiol. Endocrinol. Metab. 2001, 281, E916-E923. [CrossRef] [PubMed]

145. Nassir, F.; Wilson, B.; Han, X.; Gross, R.W.; Abumrad, N.A. CD36 is important for fatty acid and cholesterol uptake by the proximal but not distal intestine. J. Biol. Chem. 2007, 282, 19493-19501. [CrossRef] [PubMed]

146. Nguyen, D.V.; Drover, V.A.; Knopfel, M.; Dhanasekaran, P.; Hauser, H.; Phillips, M.C. Influence of class B scavenger receptors on cholesterol flux across the brush border membrane and intestinal absorption. J. Lipid Res. 2009, 50, 2235-2244. [CrossRef] 
147. Wu, A.L.; Clark, S.B.; Holt, P.R. Transmucosal triglyceride transport rates in proximal and distal rat intestine in vivo. J. Lipid Res. 1975, 16, 251-257.

148. Nauli, A.M.; Nassir, F.; Zheng, S.; Yang, Q.; Lo, C.M.; Vonlehmden, S.B.; Lee, D.; Jandacek, R.J.; Abumrad, N.A.; Tso, P. CD36 is important for chylomicron formation and secretion and may mediate cholesterol uptake in the proximal intestine. Gastroenterology 2006, 131, 1197-1207. [CrossRef]

149. Shim, J.; Moulson, C.L.; Newberry, E.P.; Lin, M.H.; Xie, Y.; Kennedy, S.M.; Miner, J.H.; Davidson, N.O. Fatty acid transport protein 4 is dispensable for intestinal lipid absorption in mice. J. Lipid Res. 2009, 50, 491-500. [CrossRef]

150. Masson, C.J.; Plat, J.; Mensink, R.P.; Namiot, A.; Kisielewski, W.; Namiot, Z.; Fullekrug, J.; Ehehalt, R.; Glatz, J.F.; Pelsers, M.M. Fatty acid- and cholesterol transporter protein expression along the human intestinal tract. PLoS ONE 2010, 5, e10380. [CrossRef]

151. Mutch, D.M.; Anderle, P.; Fiaux, M.; Mansourian, R.; Vidal, K.; Wahli, W.; Williamson, G.; Roberts, M.A. Regional variations in $\mathrm{ABC}$ transporter expression along the mouse intestinal tract. Physiol. Genom. 2004, 17, 11-20. [CrossRef] [PubMed]

152. Bojsen-Moller, K.N.; Jacobsen, S.H.; Dirksen, C.; Jorgensen, N.B.; Reitelseder, S.; Jensen, J.E.; Kristiansen, V.B.; Holst, J.J.; van Hall, G.; Madsbad, S. Accelerated protein digestion and amino acid absorption after Roux-en-Y gastric bypass. Am. J. Clin. Nutr. 2015, 102, 600-607. [CrossRef] [PubMed]

153. Dirksen, C.; Graff, J.; Fuglsang, S.; Rehfeld, J.F.; Holst, J.J.; Madsen, J.L. Energy intake, gastrointestinal transit, and gut hormone release in response to oral triglycerides and fatty acids in men with and without severe obesity. Am. J. Physiol. Gastrointest. Liver Physiol. 2019, 316, G332-G337. [CrossRef] [PubMed]

154. Little, T.J.; Feltrin, K.L.; Horowitz, M.; Smout, A.J.; Rades, T.; Meyer, J.H.; Pilichiewicz, A.N.; Wishart, J.; Feinle-Bisset, C. Dose-related effects of lauric acid on antropyloroduodenal motility, gastrointestinal hormone release, appetite, and energy intake in healthy men. Am. J. Physiol. Regul. Integr. Comp. Physiol. 2005, 289, R1090-R1098. [CrossRef]

155. Pilichiewicz, A.N.; Chaikomin, R.; Brennan, I.M.; Wishart, J.M.; Rayner, C.K.; Jones, K.L.; Smout, A.J.; Horowitz, M.; Feinle-Bisset, C. Load-dependent effects of duodenal glucose on glycemia, gastrointestinal hormones, antropyloroduodenal motility, and energy intake in healthy men. Am. J. Physiol. Endocrinol. Metab. 2007, 293, E743-E753. [CrossRef]

156. Hutchison, A.T.; Feinle-Bisset, C.; Fitzgerald, P.C.; Standfield, S.; Horowitz, M.; Clifton, P.M.; Luscombe-Marsh, N.D. Comparative effects of intraduodenal whey protein hydrolysate on antropyloroduodenal motility, gut hormones, glycemia, appetite, and energy intake in lean and obese men. Am. J. Clin. Nutr. 2015, 102, 1323-1331. [CrossRef]

157. Wu, T.; Zhang, X.; Trahair, L.G.; Bound, M.J.; Little, T.J.; Deacon, C.F.; Horowitz, M.; Jones, K.L.; Rayner, C.K. Small intestinal glucose delivery affects the lowering of blood glucose by acute vildagliptin in type 2 diabetes. J. Clin. Endocrinol. Metab. 2016, 101, 4769-4778. [CrossRef]

158. Ma, J.; Pilichiewicz, A.N.; Feinle-Bisset, C.; Wishart, J.M.; Jones, K.L.; Horowitz, M.; Rayner, C.K. Effects of variations in duodenal glucose load on glycaemic, insulin, and incretin responses in type 2 diabetes. Diabet Med. 2012, 29, 604-608. [CrossRef]

159. Trahair, L.G.; Horowitz, M.; Rayner, C.K.; Gentilcore, D.; Lange, K.; Wishart, J.M.; Jones, K.L. Comparative effects of variations in duodenal glucose load on glycemic, insulinemic, and incretin responses in healthy young and older subjects. J. Clin. Endocrinol. Metab. 2012, 97, 844-851. [CrossRef]

160. Pilichiewicz, A.N.; Papadopoulos, P.; Brennan, I.M.; Little, T.J.; Meyer, J.H.; Wishart, J.M.; Horowitz, M.; Feinle-Bisset, C. Load-dependent effects of duodenal lipid on antropyloroduodenal motility, plasma CCK and PYY, and energy intake in healthy men. Am. J. Physiol. Regul. Integr. Comp. Physiol. 2007, 293, R2170-R2178. [CrossRef]

161. Wu, T.; Rayner, C.K.; Horowitz, M. Inter-regulation of gastric emptying and incretin hormone secretion: Implications for postprandial glycemic control. Biomark. Med. 2016, 10, 1167-1179. [CrossRef] [PubMed]

162. Laferrere, B.; Heshka, S.; Wang, K.; Khan, Y.; McGinty, J.; Teixeira, J.; Hart, A.B.; Olivan, B. Incretin levels and effect are markedly enhanced 1 month after Roux-en-Y gastric bypass surgery in obese patients with type 2 diabetes. Diabetes Care 2007, 30, 1709-1716. [CrossRef] [PubMed] 
163. Dirksen, C.; Jorgensen, N.B.; Bojsen-Moller, K.N.; Kielgast, U.; Jacobsen, S.H.; Clausen, T.R.; Worm, D.; Hartmann, B.; Rehfeld, J.F.; Damgaard, M.; et al. Gut hormones, early dumping and resting energy expenditure in patients with good and poor weight loss response after Roux-en-Y gastric bypass. Int. J. Obes. 2013, 37, 1452-1459. [CrossRef] [PubMed]

164. Nguyen, N.Q.; Debreceni, T.L.; Bambrick, J.E.; Bellon, M.; Wishart, J.; Standfield, S.; Rayner, C.K.; Horowitz, M. Rapid gastric and intestinal transit is a major determinant of changes in blood glucose, intestinal hormones, glucose absorption and postprandial symptoms after gastric bypass. Obesity 2014, 22, 2003-2009. [CrossRef]

165. Mingrone, G.; Nolfe, G.; Gissey, G.C.; Iaconelli, A.; Leccesi, L.; Guidone, C.; Nanni, G.; Holst, J.J. Circadian rhythms of GIP and GLP1 in glucose-tolerant and in type 2 diabetic patients after biliopancreatic diversion. Diabetologia 2009, 52, 873-881. [CrossRef]

166. Salinari, S.; Bertuzzi, A.; Asnaghi, S.; Guidone, C.; Manco, M.; Mingrone, G. First-phase insulin secretion restoration and differential response to glucose load depending on the route of administration in type 2 diabetic subjects after bariatric surgery. Diabetes Care 2009, 32, 375-380. [CrossRef]

167. Powell, D.R.; Smith, M.; Greer, J.; Harris, A.; Zhao, S.; DaCosta, C.; Mseeh, F.; Shadoan, M.K.; Sands, A.; Zambrowicz, B.; et al. LX4211 increases serum glucagon-like peptide 1 and peptide YY levels by reducing sodium/glucose cotransporter 1 (SGLT1)-mediated absorption of intestinal glucose. J. Pharm. Exp. Ther. 2013, 345, 250-259. [CrossRef]

168. Oguma, T.; Nakayama, K.; Kuriyama, C.; Matsushita, Y.; Yoshida, K.; Hikida, K.; Obokata, N.; Tsuda-Tsukimoto, M.; Saito, A.; Arakawa, K.; et al. Intestinal sodium glucose cotransporter 1 inhibition enhances glucagon-like peptide-1 secretion in normal and diabetic rodents. J. Pharm. Exp. Ther. 2015, 354, 279-289. [CrossRef]

169. Dobbins, R.L.; Greenway, F.L.; Chen, L.; Liu, Y.; Breed, S.L.; Andrews, S.M.; Wald, J.A.; Walker, A.; Smith, C.D. Selective sodium-dependent glucose transporter 1 inhibitors block glucose absorption and impair glucose-dependent insulinotropic peptide release. Am. J. Physiol. Gastrointest. Liver Physiol. 2015, 308, G946-G954. [CrossRef]

170. He, Y.L.; Haynes, W.; Meyers, C.D.; Amer, A.; Zhang, Y.; Mahling, P.; Mendonza, A.E.; Ma, S.; Chutkow, W.; Bachman, E. The effects of licogliflozin, a dual SGLT1/2 inhibitor, on body weight in obese patients with or without diabetes. Diabetes Obes. Metab. 2019, 21, 1311-1321. [CrossRef]

171. Qualmann, C.; Nauck, M.A.; Holst, J.J.; Orskov, C.; Creutzfeldt, W. Glucagon-like peptide 1 (7-36 amide) secretion in response to luminal sucrose from the upper and lower gut. A study using alpha-glucosidase inhibition (acarbose). Scand. J. Gastroenterol. 1995, 30, 892-896. [CrossRef] [PubMed]

172. Zheng, M.Y.; Yang, J.H.; Shan, C.Y.; Zhou, H.T.; Xu, Y.G.; Wang, Y.; Ren, H.Z.; Chang, B.C.; Chen, L.M. Effects of 24-week treatment with acarbose on glucagon-like peptide 1 in newly diagnosed type 2 diabetic patients: A preliminary report. Cardiovasc. Diabetol. 2013, 12, 73. [CrossRef] [PubMed]

173. Vanis, L.; Hausken, T.; Gentilcore, D.; Rigda, R.S.; Rayner, C.K.; Feinle-Bisset, C.; Horowitz, M.; Jones, K.L. Comparative effects of glucose and xylose on blood pressure, gastric emptying and incretin hormones in healthy older subjects. Br. J. Nutr. 2011, 105, 1644-1651. [CrossRef] [PubMed]

174. Crapo, P.A.; Reaven, G.; Olefsky, J. Plasma glucose and insulin responses to orally administered simple and complex carbohydrates. Diabetes 1976, 25, 741-747. [CrossRef]

175. Wu, T.; Bound, M.J.; Zhao, B.Y.R.; Standfield, S.D.; Bellon, M.; Jones, K.L.; Horowitz, M.; Rayner, C.K. Effects of a D-xylose preload with or without sitagliptin on gastric emptying, glucagon-like peptide-1, and postprandial glycemia in type 2 diabetes. Diabetes Care 2013, 36, 1913-1918. [CrossRef]

176. Damci, T.; Yalin, S.; Balci, H.; Osar, Z.; Korugan, U.; Ozyazar, M.; Ilkova, H. Orlistat augments postprandial increases in glucagon-like peptide 1 in obese type 2 diabetic patients. Diabetes Care 2004, 27, 1077-1080. [CrossRef]

177. Ellrichmann, M.; Kapelle, M.; Ritter, P.R.; Holst, J.J.; Herzig, K.H.; Schmidt, W.E.; Schmitz, F.; Meier, J.J. Orlistat inhibition of intestinal lipase acutely increases appetite and attenuates postprandial glucagon-like peptide-1-(7-36)-amide-1, cholecystokinin, and peptide YY concentrations. J. Clin. Endocrinol. Metab. 2008, 93, 3995-3998. [CrossRef]

178. Enc, F.Y.; Ones, T.; Akin, H.L.; Dede, F.; Turoglu, H.T.; Ulfer, G.; Bekiroglu, N.; Haklar, G.; Rehfeld, J.F.; Holst, J.J.; et al. Orlistat accelerates gastric emptying and attenuates GIP release in healthy subjects. Am. J. Physiol. Gastrointest. Liver Physiol. 2009, 296, G482-G489. [CrossRef] 
179. O’Donovan, D.; Horowitz, M.; Russo, A.; Feinle-Bisset, C.; Murolo, N.; Gentilcore, D.; Wishart, J.M.; Morris, H.A.; Jones, K.L. Effects of lipase inhibition on gastric emptying of, and on the glycaemic, insulin and cardiovascular responses to, a high-fat/carbohydrate meal in type 2 diabetes. Diabetologia 2004, 47, 2208-2214. [CrossRef]

180. Chaikomin, R.; Wu, K.L.; Doran, S.; Meyer, J.H.; Jones, K.L.; Feinle-Bisset, C.; Horowitz, M.; Rayner, C.K. Effects of mid-jejunal compared to duodenal glucose infusion on peptide hormone release and appetite in healthy men. Regul. Pept. 2008, 150, 38-42. [CrossRef]

181. Wu, T.; Thazhath, S.S.; Marathe, C.S.; Bound, M.J.; Jones, K.L.; Horowitz, M.; Rayner, C.K. Comparative effect of intraduodenal and intrajejunal glucose infusion on the gut-incretin axis response in healthy males. Nutr. Diabetes 2015, 5, e156. [CrossRef] [PubMed]

182. Rigda, R.S.; Trahair, L.G.; Little, T.J.; Wu, T.; Standfield, S.; Feinle-Bisset, C.; Rayner, C.K.; Horowitz, M.; Jones, K.L. Regional specificity of the gut-incretin response to small intestinal glucose infusion in healthy older subjects. Peptides 2016, 86, 126-132. [CrossRef] [PubMed]

183. Poppitt, S.D.; Shin, H.S.; McGill, A.T.; Budgett, S.C.; Lo, K.; Pahl, M.; Duxfield, J.; Lane, M.; Ingram, J.R. Duodenal and ileal glucose infusions differentially alter gastrointestinal peptides, appetite response, and food intake: A tube feeding study. Am. J. Clin. Nutr 2017, 106, 725-735. [CrossRef] [PubMed]

184. Mangan, A.M.; Al Najim, W.; McNamara, N.; Martin, W.P.; Antanaitis, A.; Bleiel, S.B.; Kent, R.M.; le Roux, C.W.; Docherty, N.G. Effect of macronutrient type and gastrointestinal release site on PYY response in normal healthy subjects. J. Clin. Endocrinol. Metab. 2019, 104, 3661-3669. [CrossRef]

185. Maljaars, P.W.; Symersky, T.; Kee, B.C.; Haddeman, E.; Peters, H.P.; Masclee, A.A. Effect of ileal fat perfusion on satiety and hormone release in healthy volunteers. Int. J. Obes. 2008, 32, 1633-1639. [CrossRef]

186. van Avesaat, M.; Troost, F.J.; Ripken, D.; Hendriks, H.F.; Masclee, A.A. Ileal brake activation: Macronutrient-specific effects on eating behavior? Int. J. Obes. 2015, 39, 235-243. [CrossRef]

187. Christiansen, C.B.; Gabe, M.B.N.; Svendsen, B.; Dragsted, L.O.; Rosenkilde, M.M.; Holst, J.J. The impact of short-chain fatty acids on GLP-1 and PYY secretion from the isolated perfused rat colon. Am. J. Physiol. Gastrointest. Liver Physiol. 2018, 315, G53-G65. [CrossRef]

188. Tolhurst, G.; Heffron, H.; Lam, Y.S.; Parker, H.E.; Habib, A.M.; Diakogiannaki, E.; Cameron, J.; Grosse, J.; Reimann, F.; Gribble, F.M. Short-chain fatty acids stimulate glucagon-like peptide-1 secretion via the G-protein-coupled receptor FFAR2. Diabetes 2012, 61, 364-371. [CrossRef]

189. Psichas, A.; Sleeth, M.L.; Murphy, K.G.; Brooks, L.; Bewick, G.A.; Hanyaloglu, A.C.; Ghatei, M.A.; Bloom, S.R.; Frost, G. The short chain fatty acid propionate stimulates GLP-1 and PYY secretion via free fatty acid receptor 2 in rodents. Int. J. Obes. 2015, 39, 424-429. [CrossRef]

190. Freeland, K.R.; Wolever, T.M. Acute effects of intravenous and rectal acetate on glucagon-like peptide-1, peptide YY, ghrelin, adiponectin and tumour necrosis factor-alpha. Br. J. Nutr. 2010, 103, 460-466. [CrossRef]

191. Chambers, E.S.; Viardot, A.; Psichas, A.; Morrison, D.J.; Murphy, K.G.; Zac-Varghese, S.E.; MacDougall, K.; Preston, T.; Tedford, C.; Finlayson, G.S.; et al. Effects of targeted delivery of propionate to the human colon on appetite regulation, body weight maintenance and adiposity in overweight adults. Gut 2015, 64, 1744-1754. [CrossRef] [PubMed]

192. Canfora, E.E.; van der Beek, C.M.; Jocken, J.W.E.; Goossens, G.H.; Holst, J.J.; Olde Damink, S.W.M.; Lenaerts, K.; Dejong, C.H.C.; Blaak, E.E. Colonic infusions of short-chain fatty acid mixtures promote energy metabolism in overweight/obese men: A randomized crossover trial. Sci. Rep. 2017, 7, 2360. [CrossRef] [PubMed]

193. Christiansen, C.B.; Trammell, S.A.J.; Wewer Albrechtsen, N.J.; Schoonjans, K.; Albrechtsen, R.; Gillum, M.P.; Kuhre, R.E.; Holst, J.J. Bile acids drive colonic secretion of glucagon-like-peptide 1 and peptide-YY in rodents. Am. J. Physiol. Gastrointest. Liver Physiol. 2019, 316, G574-G584. [CrossRef]

194. Petersen, N.; Reimann, F.; Bartfeld, S.; Farin, H.F.; Ringnalda, F.C.; Vries, R.G.; van den Brink, S.; Clevers, H.; Gribble, F.M.; de Koning, E.J. Generation of L cells in mouse and human small intestine organoids. Diabetes 2014, 63, 410-420. [CrossRef] [PubMed]

195. Rudling, M.; Camilleri, M.; Graffner, H.; Holst, J.J.; Rikner, L. Specific inhibition of bile acid transport alters plasma lipids and GLP-1. BMC Cardiovasc Disord. 2015, 15, 75. [CrossRef] [PubMed]

196. Wu, T.; Bound, M.J.; Standfield, S.D.; Gedulin, B.; Jones, K.L.; Horowitz, M.; Rayner, C.K. Effects of rectal administration of taurocholic acid on glucagon-like peptide-1 and peptide YY secretion in healthy humans. Diabetes Obes. Metab. 2013, 15, 474-477. [CrossRef] [PubMed] 
197. Adrian, T.E.; Gariballa, S.; Parekh, K.A.; Thomas, S.A.; Saadi, H.; Al Kaabi, J.; Nagelkerke, N.; Gedulin, B.; Young, A.A. Rectal taurocholate increases L cell and insulin secretion, and decreases blood glucose and food intake in obese type 2 diabetic volunteers. Diabetologia 2012, 55, 2343-2347. [CrossRef]

198. Marathe, C.S.; Rayner, C.K.; Jones, K.L.; Horowitz, M. Relationships between gastric emptying, postprandial glycemia, and incretin hormones. Diabetes Care 2013, 36, 1396-1405. [CrossRef]

199. Watson, L.E.; Xie, C.; Wang, X.; Li, Z.; Phillips, L.K.; Sun, Z.; Jones, K.L.; Horowitz, M.; Rayner, C.K.; Wu, T. Gastric emptying in patients with well-controlled type 2 diabetes compared with young and older control subjects without diabetes. J. Clin. Endocrinol. Metab. 2019, 104, 3311-3319. [CrossRef]

200. Seimon, R.V.; Brennan, I.M.; Russo, A.; Little, T.J.; Jones, K.L.; Standfield, S.; Wishart, J.M.; Horowitz, M.; Feinle-Bisset, C. Gastric emptying, mouth-to-cecum transit, and glycemic, insulin, incretin, and energy intake responses to a mixed-nutrient liquid in lean, overweight, and obese males. Am. J. Physiol. Endocrinol. Metab. 2013, 304, E294-E300. [CrossRef]

201. Perano, S.J.; Rayner, C.K.; Kritas, S.; Horowitz, M.; Donaghue, K.; Mpundu-Kaambwa, C.; Giles, L.; Couper, J.J. Gastric Emptying Is More Rapid in Adolescents With Type 1 Diabetes and Impacts on Postprandial Glycemia. J. Clin. Endocrinol. Metab. 2015, 100, 2248-2253. [CrossRef] [PubMed]

202. Jones, K.L.; Horowitz, M.; Wishart, J.M.; Maddox, A.F.; Harding, P.E.; Chatterton, B.E. Relationships between gastric-emptying, intragastric meal distribution and blood-glucose concentrations in diabetes-mellitus. J. Nucl. Med. 1995, 36, 2220-2228. [PubMed]

203. Watson, L.E.; Phillips, L.K.; Wu, T.; Bound, M.J.; Checklin, H.L.; Grivell, J.; Jones, K.L.; Clifton, P.M.; Horowitz, M.; Rayner, C.K. A whey/guar "preload" improves postprandial glycaemia and glycated haemoglobin levels in type 2 diabetes: A 12-week, single-blind, randomized, placebo-controlled trial. Diabetes Obes. Metab. 2019, 21, 930-938. [CrossRef] [PubMed]

204. Ghazi, T.; Rink, L.; Sherr, J.L.; Herold, K.C. Acute metabolic effects of exenatide in patients with type 1 diabetes with and without residual insulin to oral and intravenous glucose challenges. Diabetes Care 2014, 37, 210-216. [CrossRef] [PubMed]

205. Wu, T.; Little, T.J.; Bound, M.J.; Borg, M.; Zhang, X.; Deacon, C.F.; Horowitz, M.; Jones, K.L.; Rayner, C.K. A protein preload enhances the glucose-lowering efficacy of vildagliptin in type 2 diabetes. Diabetes Care 2016, 39, 511-517. [CrossRef]

206. Vilsbøll, T.; Krarup, T.; Madsbad, S.; Holst, J.J. Both GLP-1 and GIP are insulinotropic at basal and postprandial glucose levels and contribute nearly equally to the incretin effect of a meal in healthy subjects. Regul. Pept. 2003, 114, 115-121. [CrossRef]

207. Alleleyn, A.M.; van Avesaat, M.; Troost, F.J.; Masclee, A.A. Gastrointestinal nutrient infusion site and eating behavior: Evidence for a proximal to distal gradient within the small intestine? Nutrients 2016, 8, 117. [CrossRef]

208. Maljaars, P.W.; Peters, H.P.; Kodde, A.; Geraedts, M.; Troost, F.J.; Haddeman, E.; Masclee, A.A. Length and site of the small intestine exposed to fat influences hunger and food intake. Br. J. Nutr. 2011, 106, 1609-1615. [CrossRef]

209. Ma, J.; Checklin, H.L.; Wishart, J.M.; Stevens, J.E.; Jones, K.L.; Horowitz, M.; Meyer, J.H.; Rayner, C.K. A randomised trial of enteric-coated nutrient pellets to stimulate gastrointestinal peptide release and lower glycaemia in type 2 diabetes. Diabetologia 2013, 56, 1236-1242. [CrossRef]

210. Calderon, G.; McRae, A.; Rievaj, J.; Davis, J.; Zandvakili, I.; Linker-Nord, S.; Burton, D.; Roberts, G.; Reimann, F.; Gedulin, B.; et al. Ileo-colonic delivery of conjugated bile acids improves glucose homeostasis via colonic GLP-1-producing enteroendocrine cells in human obesity and diabetes. EBioMedicine 2020, 55, 102759. [CrossRef]

211. Fruhbeck, G. Bariatric and metabolic surgery: A shift in eligibility and success criteria. Nat. Rev. Endocrinol. 2015, 11, 465-477. [CrossRef] [PubMed]

212. Rubino, F.; Schauer, P.R.; Kaplan, L.M.; Cummings, D.E. Metabolic surgery to treat type 2 diabetes: Clinical outcomes and mechanisms of action. Annu. Rev. Med. 2010, 61, 393-411. [CrossRef] [PubMed]

213. Jørgensen, N.B.; Dirksen, C.; Bojsen-Møller, K.N.; Jacobsen, S.H.; Worm, D.; Hansen, D.L.; Kristiansen, V.B.; Naver, L.; Madsbad, S.; Holst, J.J. The exaggerated glucagon-like peptide-1 response is important for the improved $\beta$-cell function and glucose tolerance after Roux-en-Y gastric bypass in patients with type 2 diabetes. Diabetes 2013, 62, 3044-3052. [CrossRef] [PubMed] 
214. Svane, M.S.; Bojsen-Moller, K.N.; Nielsen, S.; Jorgensen, N.B.; Dirksen, C.; Bendtsen, F.; Kristiansen, V.B.; Hartmann, B.; Holst, J.J.; Madsbad, S. Effects of endogenous GLP-1 and GIP on glucose tolerance after Roux-en-Y gastric bypass surgery. Am. J. Physiol. Endocrinol. Metab. 2016, 310, E505-E514. [CrossRef]

215. Svane, M.S.; Jorgensen, N.B.; Bojsen-Moller, K.N.; Dirksen, C.; Nielsen, S.; Kristiansen, V.B.; Torang, S.; Wewer Albrechtsen, N.J.; Rehfeld, J.F.; Hartmann, B.; et al. Peptide YY and glucagon-like peptide-1 contribute to decreased food intake after Roux-en-Y gastric bypass surgery. Int. J. Obes. 2016, 40, 1699-1706. [CrossRef]

216. Nicholson, J.K.; Holmes, E.; Kinross, J.; Burcelin, R.; Gibson, G.; Jia, W.; Pettersson, S. Host-gut microbiota metabolic interactions. Science 2012, 336, 1262-1267. [CrossRef]

217. Seck, E.H.; Senghor, B.; Merhej, V.; Bachar, D.; Cadoret, F.; Robert, C.; Azhar, E.I.; Yasir, M.; Bibi, F.; Jiman-Fatani, A.A.; et al. Salt in stools is associated with obesity, gut halophilic microbiota and Akkermansia muciniphila depletion in humans. Int. J. Obes. 2019, 43, 862-871. [CrossRef]

218. Canfora, E.E.; Meex, R.C.R.; Venema, K.; Blaak, E.E. Gut microbial metabolites in obesity, NAFLD and T2DM. Nat. Rev. Endocrinol. 2019, 15, 261-273. [CrossRef]

219. Wahlstrom, A.; Sayin, S.I.; Marschall, H.U.; Backhed, F. Intestinal crosstalk between bile acids and microbiota and its impact on host metabolism. Cell Metab. 2016, 24, 41-50. [CrossRef]

220. De Vadder, F.; Kovatcheva-Datchary, P.; Goncalves, D.; Vinera, J.; Zitoun, C.; Duchampt, A.; Backhed, F.; Mithieux, G. Microbiota-generated metabolites promote metabolic benefits via gut-brain neural circuits. Cell 2014, 156, 84-96. [CrossRef]

221. Byrne, C.S.; Chambers, E.S.; Alhabeeb, H.; Chhina, N.; Morrison, D.J.; Preston, T.; Tedford, C.; Fitzpatrick, J.; Irani, C.; Busza, A.; et al. Increased colonic propionate reduces anticipatory reward responses in the human striatum to high-energy foods. Am. J. Clin. Nutr. 2016, 104, 5-14. [CrossRef] [PubMed]

(C) 2020 by the authors. Licensee MDPI, Basel, Switzerland. This article is an open access article distributed under the terms and conditions of the Creative Commons Attribution (CC BY) license (http://creativecommons.org/licenses/by/4.0/). 